\title{
Range Front Faulting and Volcanism in the Mono Basin, Eastern California
}

\author{
MARCUS BURSIK ${ }^{1}$ AND KERRY SIEH \\ Division of Geological and Planetary Sciences, California Institute of Technology, Pasadena
}

\begin{abstract}
The spatial and temporal pattern of range front normal faulting and volcanism in the Mono Basin of eastern California suggests that dikes are being intruded underneath the Mono Craters in response to crustal stretching and are now accommodating strain that was once taken up by range front faulting. The section of the Sierra Nevadan range front near the craters accommodated as much as $1 \mathrm{~mm} / \mathrm{yr}$ of extension as recently as about 40,000 years ago. For the past 40,000 years, this section of range front has been inactive, even though range front extension to the north and south has continued at up to $0.9 \mathrm{~mm} / \mathrm{yr}$. For the past 40,000 years, dikes, intruding underneath the Mono Craters, seem to have been accommodating the $1 \mathrm{~mm} / \mathrm{yr}$ of extension that was previously taken up by faulting. Since the basin is extending obliquely to the trend of the frontal faults, there is a component of dextral shear to their motion, so that the Mono Craters may be forming on an extensional boundary of a pull-apart basin. If the craters represent incipient caldera formation, then calderas such as Long Valley may also have formed in pull-apart zones.
\end{abstract}

\section{INTRODUCTION}

Various workers have given examples of eruption centers or dikes that were formed in response to regional tectonic stresses in the continental environment [Ode, 1957; Muller and Pollard, 1977; Nakamura, 1977; Delaney and Pollard, 1979; Bacon et al., 1980; Roquemore, 1980; Fink and Pollard, 1983; Fink, 1985]. Lachenbruch and Sass [1978] suggested that dike intrusion as well as normal faulting is a mechanism for strain relief throughout the Basin Ranges. Bacon [1982] attempted to link the rate of volcanic activity to tectonic extension in the Coso Volcanic Field. We have studied the Mono Craters and the Sierra Nevadan range front to understand how the construction of a volcanic chain and underlying intrusion of magma can be quantitatively related to tectonic forces responsible for range front faulting.

The Mono Basin lies on the western margin of the Basin Ranges, east of the central Sierra Nevada (Figure 1). In this study, the Mono Basin is considered that area bounded by the Bodie Hills, Cowtrack Mountain, Long Valley Caldera, and the Sierra Nevada on north, east, south, and west. The area has been the site of extensive volcanic and tectonic activity in late Quaternary time [Bailey et al., 1976] and is ideal for comparison of the geologic record of active volcanic and tectonic processes because (1) the record of volcanism at the Mono Craters has been extensively studied, so that constraints can be placed on the ages and styles of dome formation, (2) the record of surficial fault slip along rangebounding faults is relatively complete over the past 100,000 years, and (3) the apparent lack of latest Quaternary faulting on the section of the range front directly opposite the Mono Craters suggests that intrusions which feed the craters are accommodating strain that was once taken up by range

\footnotetext{
${ }^{1}$ Now at Department of Earth Sciences, University of Cambridge, England.
}

Copyright 1989 by the American Geophysical Union.

Paper number 89JB00848.

0148-0227/89/89JB-00848 $\$ 05.00$ front normal faulting. The testing of this hypothesis served as motivation for our work.

Huber [1981] hypothesized that the Mono Basin-Long Valley region began down-dropping relative to the Sierra Nevada about $3 \mathrm{~m} . y$. ago. Since that time, differential motion between the highest part of the basin, at Hartley Springs (Figure 1), and the crest of the Sierra Nevada has been about $1100 \mathrm{~m}$. Huber [1981] was unable to extrapolate his work to the north and south along the range front, but the conclusion of Gilbert et al. [1968], that much of the movement on the Cowtrack Mountain range front (Figure 1) also occurred after 3 to 4 m.y. ago, supports Huber's hypothesis.

Pakiser et al. [1960] used mostly gravity data to show that $6 \mathrm{~km}$ of subsidence had occurred on a set of nearly vertical faults roughly underlying the shore of Mono Lake. Gilbert et al. [1968] showed that the gravity anomalies reported by Pakiser et al. [1960] could be explained with a basin only $1 \mathrm{~km}$ deep, by assuming more reasonable values for the density contrast between Cenozoic sediment and basement rock. Based on detailed mapping of the area, Gilbert et al. [1968] found that the Mono Basin is a northward plunging graben from the northern edge of Long Valley Caldera to the center of Mono Lake. The northern boundary consists of a west trending monocline, with subordinate faulting, that dips southward from the Bodie Hills to the center of the lake. The lack of voluminous volcanic rock around the basin fit their interpretation that it is not a volcanotectonic depression. Pakiser [1976], using seismic refraction profiles, concluded that the Mono Basin is 2 to $2.5 \mathrm{~km}$ deep underneath Mono Lake. Underneath the Mono Craters, the depth to basement is less than $300 \mathrm{~m}$ [Putnam, 1949; Gilbert et al., 1968; Hill et al., 1985].

\section{Amount And Timing Of Offsets On The Range Front Faults}

Data

Since our primary goal was to constrain the amount and timing of slip along the faults of the Mono Basin, we both mapped faults and measured offsets of dated late Quater- 


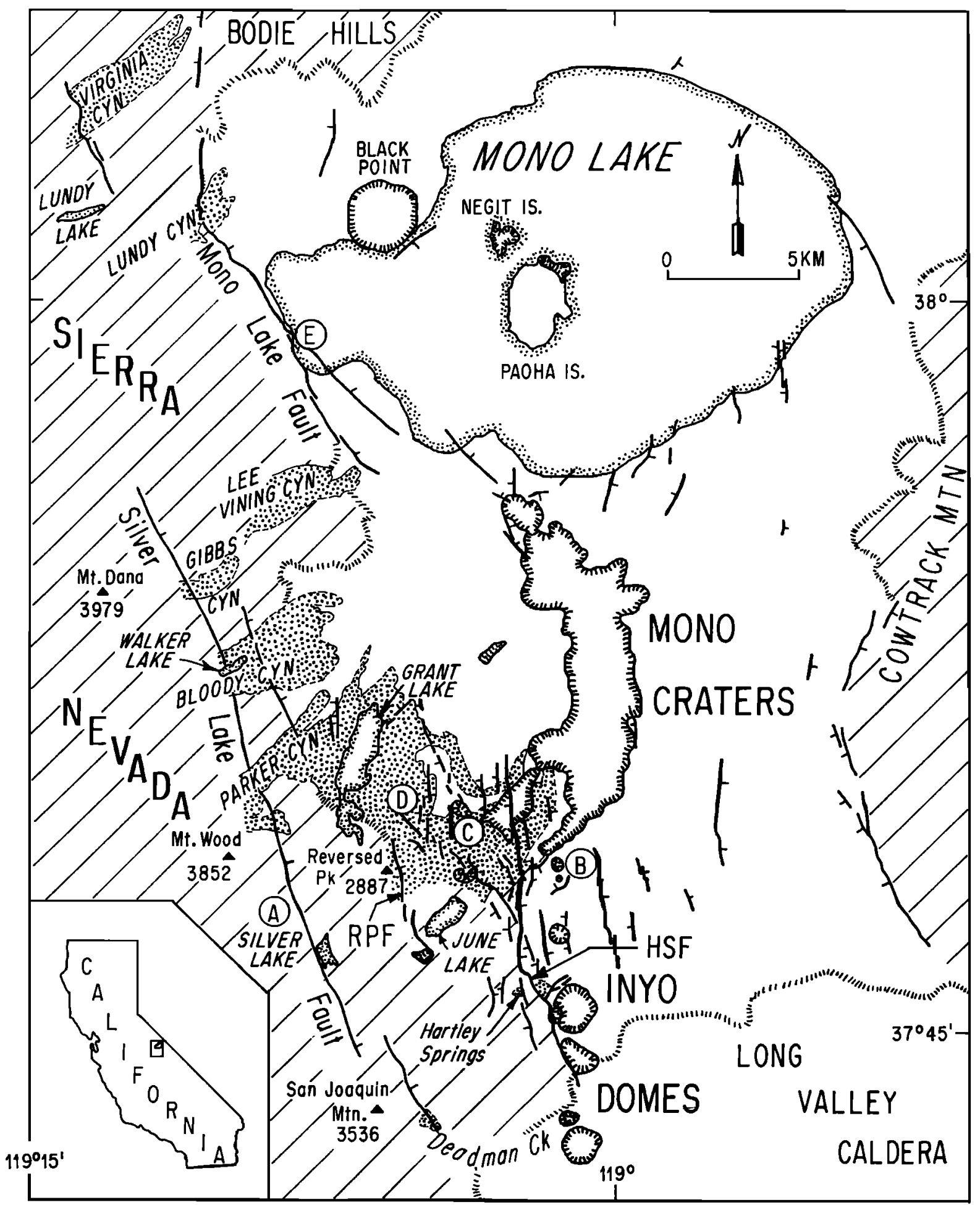

Fig. 1. The Mono Basin is situated east of the Sierra Nevada, between Long Valley Caldera and the Bodie Hills. HSF is Hartley Springs Fault, RPF is Reversed Peak Fault. Lettered localities are referred to in the text. Faulted glacial moraines (stipple) reveal some of the history of faulting in the basin and its relationship to volcanism. All faults which break mid-Pleistocene or younger material are shown, except those within the volcanic edifices. The Silver Lake Fault and the fault at Virginia Creek are not mapped into terrain where they do not form bedrock escarpments. See Plate 1 of Bursik [1988] for a more detailed map. 
nary landforms and deposits. Our data consist of a tectonic map of the Mono Basin, and approximately 50 profiles of scarp slopes and measurements of scarp heights across faults active in middle to late Quaternary time.

A fault map (summarized in Figure 1) was constructed by field mapping and checking of fault scarps initially mapped in the office from U.S. Forest Service aerial photographs with a nominal scale of 1:20,000. A larger scale version of this map appears in the work by Bursik [1988]. Only faults with known or possible offset in the middle to late Quaternary period are depicted in the figure.

After the map was completed, we measured topographic profiles of fault scarps to quantify offsets. Most scarp profiles were made along moraine crests for three important reasons: (1) Glacial moraines issue from the mouths of all major canyons and cross the frontal fault system, providing datable late Quaternary features that can be correlated throughout the area. (2) Scarps are better preserved on moraine crests than on any other landform. (3) It is easier to estimate the ages of moraines than the ages of any other landforms. Scarp profile data and the chronology of the moraines are given by Bursik [1988]. Moraine ages are summarized in Table 1.

TABLE 1. Ages of Pleistocene Glaciations of the Mono Basin

\begin{tabular}{lcc}
\hline $\begin{array}{c}\text { Glacial Stage } \\
\text { Names Used in } \\
\text { This Study }\end{array}$ & $\begin{array}{c}\text { Age, } \\
\text { Best } \\
\text { Estimate }\end{array}$ & $\begin{array}{c}\text { Age, } \\
\text { Range }\end{array}$ \\
\hline Tioga & 14,000 & $11,000-21,000$ \\
Tenaya & 40,000 & $34,000-43,000$ \\
Tahoe & 66,000 & $60,000-85,000$ \\
Mono Basin & 130,000 & $130,000-198,000$ \\
Pre-Mono Basin II & 200,000 & $?$ \\
Sherwin & 750,000 & $708,000-900,000$ \\
\hline
\end{tabular}

aFrom Gillespie [1982], Crook and Gullespie [1986], and Bursik [1988].

betails on limiting ages can be found in Bursik, [1988].

We surveyed fault scarps with a Wild-Heerbrugg TC-2000 total station geodimeter or with a 2- or 4-m stadia rod and Abney level. Profiles of fault scarps on the order of 50 to $100 \mathrm{~m}$ high, at June Lake, Hartley Springs, and Lundy Canyon, were constructed from U.S. Geological Survey 7.5 arc min topographic maps having 40 -foot (12-m) contour intervals. We constructed a profile of the large fault scarp in the pre-Mono Basin II right lateral moraine at Sawmill Canyon from the 15 arc min map of the Mono Craters quadrangle, which has an 80 -foot $(24-\mathrm{m})$ contour interval. We walked out and noted features along all scarps made from topographic maps, both to ensure that upper and lower surfaces were correlative and to note what fraction of the scarp heights could reasonably be attributed to faulting. Nomenclature of fault scarp profiles is depicted in Figure 2. Note in particular that vertical offset and vertical slip are the same only for vertical faults.

\section{Errors in Scarp Profile Measurements}

Uncertainties in slip measurements derived from scarp profiles cannot be measured with precision, but are of two types: (1) measurement uncertainty in the instruments and (2) uncertainty in fault, slip vector, or offset surface orien-

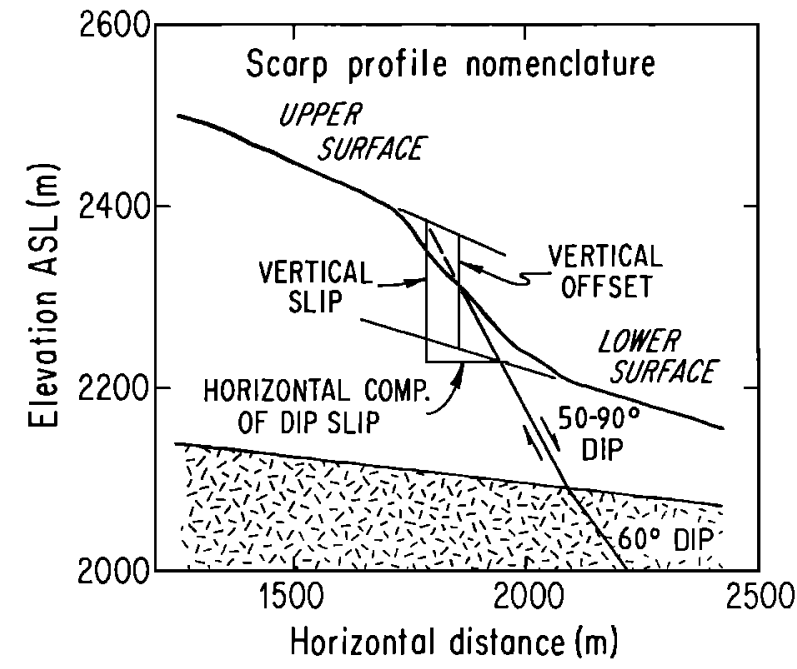

Fig. 2. Nomenclature of scarp profile measurements. Vertical offset is the vertical distance between the upper and lower surfaces measured at the midpoint of the steepest segment of the profile, or at the midpoint of the profile if the steepest segment is poorly defined. Vertical slip is the vertical component of dip slip.

tation. Measurement uncertainty in total station, rod-andlevel, and map-profile measurements are much smaller than uncertainties in fault orientation and will not be discussed further. Uncertainties in orientation can be resolved into four components: (1) dip of upper and lower offset surfaces, (2) position of intersection of fault plane and scarp, (3) strike and dip of slip vector, and (4) dip of fault plane. Below, we address each of these uncertainties.

Swan et al. [1980] showed examples from the Hobble Creek site along the Wasatch Fault of uncertainty in the dips of offset surfaces. The most serious uncertainty that can arise when estimating the position and dip of offset surfaces occurs where there is a zone of back-tilting near the main scarp. If offsets are measured within this zone, slips can be overestimated by more than $100 \%$. All profiles from this study were therefore measured beyond any possible backtilted zone. Even where back-tilted zones are properly taken into consideration, a small error is inherent in estimating the dip of offset surfaces, as suggested by Figure 11 of Swan et al. [1980]. Because estimation of its magnitude is somewhat subjective, this error was not assessed.

For profiles in which the upper and lower surfaces have slightly different dips, an uncertainty in the amount of slip will arise if the position of the intersection of the fault plane and the scarp is not known. We assumed that fault planes intersect scarps in the middle of the most steeply dipping slope segment. For profiles in which the position of the most steeply dipping segment was not known, for example in some of the profiles measured from topographic maps, the fault was assumed to intersect the midpoint of the scarp, as suggested by Nash [1980]. The error in location of the intersection of fault and scarp cannot at this time be evaluated, for lack of sufficient sites at which both scarp profiles and subsurface fault exposures are available.

The largest errors in deriving horizontal-slip rates from scarp profiles are caused by ignorance of the orientation of the slip vector. For a few profiles in this study, the position of the moraine crest, in map view, could be measured carefully enough to estimate the strike of the average slip vector. 
However, these values cannot be used throughout the entire region. Therefore, when we evaluated horizontal slips, we calculated their values perpendicular to the average trend of each fault (horizontal component of dip slip in Figure 2).

True dips of fault planes for all profiles measured in this study are unknown. However, other studies of new scarps, and subsurface and bedrock exposures in the Basin Ranges indicate that pristine fault scarps dip $50^{\circ}-90^{\circ}$ in unconsolidated material, and that faults in bedrock dip $55^{\circ}-75^{\circ}$ [Page, 1934; Slemmons, 1957; Myers and Hamilton, 1964; Witkind, 1964; Wallace, 1977; Lubetkin, 1980; Swan et al., 1980]. Since dips in unconsolidated, surficial materials are almost always greater than dips in bedrock, but also quite variable, we used the vertical slips calculated assuming fault dips of $50^{\circ}$ and $90^{\circ}$ as the range in possible vertical slips and the average of these two values as the best estimate of vertical slip (Figure 2). Horizontal slips (extensions) were calculated by assuming fault dips in bedrock of $60^{\circ}$, as suggested by the Coulomb criterion and by bedrock dips noted above. In the figures to follow, only uncertainties related to different fault dips are shown, as these are the largest uncertainties that can be objectively estimated.

\section{Discussion of Scarps}

Hartley Springs Fault. Two separate strands of the Hartley Springs Fault offset Tahoe till (60,000 to 85,000 years old) at Hartley Springs (Figure 3). The western strand forms a spectacular, nearly vertical, west facing scarp in Bishop Tuff. The upper surface of this scarp consists of Bishop Tuff on top of which lie Tahoe erratics. The eastern escarpment consists of several east facing slope facets, only the lowest of which seems to have been formed during post-Tahoe faulting. The upper facets dip at angles sufficiently low to suggest that they are probably preexisting scarps over which the Tahoe glacier cascaded. Total vertical offset across both strands is $64 \mathrm{~m}$, corresponding to an average total vertical slip rate since Tahoe time of about $1 \mathrm{~mm} / \mathrm{yr}$. Net motion of the Sierra Nevada relative to Mono Basin on these two strands alone has been downward, since

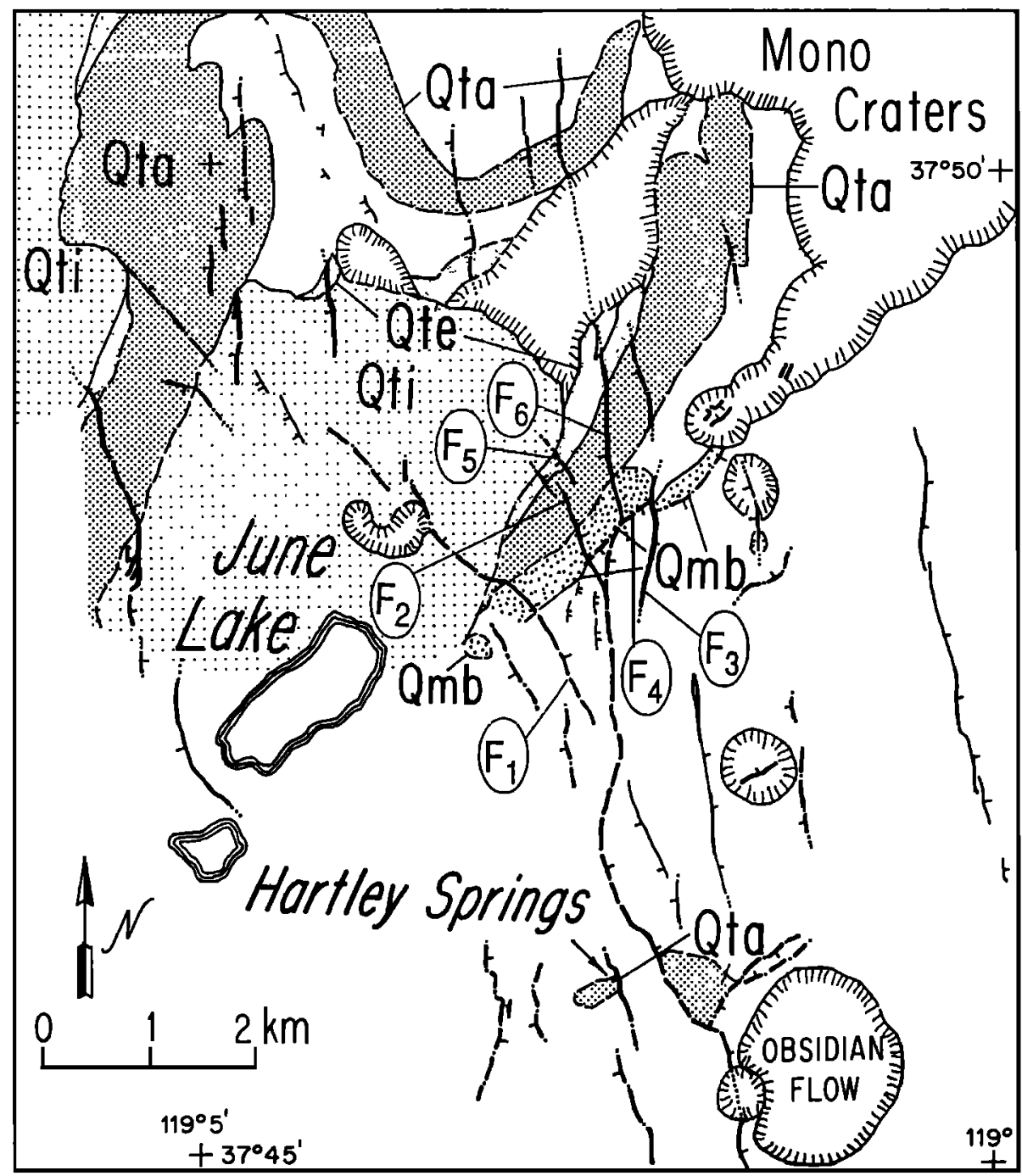

Fig. 3. Active faults in the June Lake area. Numbered strands of the Hartley Springs Fault have oval labels. Contacts and faults are dashed where approximately located, dotted and dashed where existence is uncertain. Morainal contacts are shown in thin lines. Moraines are as follows: Qmb is Mono Basin; Qta is Tahoe; Qte is Tenaya; and Qti is Tioga. 
the west facing scarp is higher. In addition, the slip rate may be a minimum value because only erratics and not an entire moraine crop out on the upthrown horst between the two faults, indicating that the till has been largely removed by erosion.

In the bedrock plateau west of Hartley Springs, several normal faults offset June Lake Granite. These faults may be quite young, since one is bordered by steep-walled collapse pits tens of meters in diameter and several meters deep; however, slip rates cannot be estimated because of lack of datable material.

Three major strands of the Hartley Springs Fault displace right-lateral moraines near June Lake (Figure 3) down to the east. These faults $\left(F_{1}\right.$ to $\left.F_{3}\right)$ together down-drop the Mono Basin moraine (130,000 to 200,000 years old) $210 \mathrm{~m}$. A fourth, obliquely trending strand $\left(\mathrm{F}_{4}\right)$ may displace the moraine as much as several tens of meters, since in the roadcut along U.S. Highway 395, the moraine overlies Bishop Tuff on the footwall block of $F_{4}$, whereas only colluvium crops out on the headwall block. Inboard of the Mono Basin moraine, $F_{1}$ and $F_{2}$ cross a group of Tahoe moraines $(60,000$ to 85,000 years old). Twenty meters of vertical displacement are visible on the western scarp $\left(F_{1}\right)$, and $10 \mathrm{~m}$ on the eastern scarp $\left(F_{2}\right)$. Faults $F_{5}$ and $F_{6}$ offset the Tahoe moraines down to the west. The scarp of $F_{5}$ is visible only on aerial photographs, because it was destroyed by rerouting of U.S. Highway $395 . F_{6}$ offsets the Tahoe moraines $7 \mathrm{~m}$. Measurement of faulting of Tenaya (34,000 to 43,000 years old) and Tioga (11,000 to 21,000 years old) moraines by $F_{1}$ is problematic. Depending on the interpretation of the complex relationships, the Tenaya moraine is offset either 7 or $13 \mathrm{~m}$, and the Tioga moraine is either unfaulted or offset $6 \mathrm{~m}$ [Bursik, 1988]. The Tenaya moraine is also offset $4 \mathrm{~m}$ by $F_{2}, 15 \mathrm{~m}$ by $F_{5}$, and $3 \mathrm{~m}$ by $F_{6}$. The Tioga moraines are not offset by $F_{2}$ through $F_{5} . F_{6}$ does not seem to offset the basaltic flow northeast of June Lake, which is between Tioga and Tenaya till in age. Figure 4 summarizes the total vertical slip on all strands of the Hartley Springs Fault at June Lake. Given the uncertainties in the ages of the moraines, the data are compatible with an average vertical slip rate of about $0.9 \mathrm{~mm} / \mathrm{yr}$ since Mono Basin time. Use of best estimates for ages of the moraines, however, suggests that the slip rate has been decreasing from at least Tahoe time to the present. There may even be no slip since Tioga time.

Reversed Peak Fault. North and east of Reversed Peak, a prominent strand of the range front fault offsets Tahoe, Tenaya, and Tioga moraines of Grant and June Lakes 21, 16 , and $4 \mathrm{~m}$, respectively, down to the east. To the south, the fault crosscuts Tioga recessional moraines before dying out(?) in ground moraine northwest of June Lake. Further south, a conjugate strand may offset recessional Tioga outwash north of Gull Lake, as suggested by excavations there. Figure 4 suggests that a higher rate of faulting along the Reversed Peak Fault occurred between Tenaya and Tioga time than that prevailing during Tahoe to Tenaya time. The data do not rule out the possibility that this higher rate of faulting has continued to the present day, since all measurements in the period from Tioga time to the present should be considered minima (a 3-m faulting event may occur tomorrow, for example). Even at its fastest vertical slip rate of $0.5 \mathrm{~mm} / \mathrm{yr}$, however, the Reversed Peak Fault only ac-

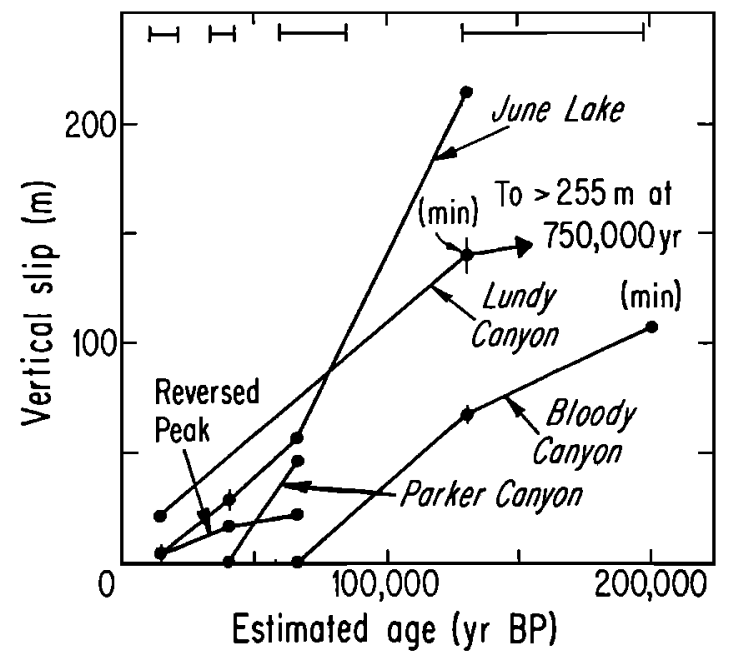

Fig. 4. Vertical slip versus age graph for faults of the Mono Basin. Error bars enclose ranges in vertical slips assuming fault dips of $50^{\circ}$ and $90^{\circ}$. Horizontal error bars at top of graph show ranges in glaciation ages from Table 1.

commodated about one-half the strain of other range front faults.

The Silver Lake Fault and the range front between Parker and Bloody Canyons. The moraines of Parker and Bloody Canyons cross two major range front structures. The Silver Lake Fault extends north-northwest from the western boundary of Long Valley Caldera into the Mono Basin. The topographic expression of this fault dies out near Lee Vining Canyon, but the range front fault at Virginia Creek may be a splay of it [Kistler, 1966; Chesterman and Gray, 1975]. The other fault defines the range front proper, and its topographic expression dies out somewhere near Lee Vining Canyon, like that of the Silver Lake Fault. It does not offset the moraines of Parker Canyon and breaks only the oldest moraines of Bloody Canyon.

The most prominent fault not bounding the present-day range is the Silver Lake Fault, which divides the peaks and plateaux of the High Sierra on the west from a lower plateau on the east uplifted along the Hartley Springs and Reversed Peak Faults. Nowhere from its intersection with Long Valley Caldera to Silver Lake does the fault convincingly offset late Quaternary material. In particular, at Deadman Creek (Figure 1), glaciers issuing from a cirque on the east face of San Joaquin Mountain crossed the fault where it joins the western limb of the Long Valley Caldera ring fracture. The upper surface of an escarpment in the left-lateral moraine crest is probably a heavily weathered bedrock knoll overlain with a thin veneer of till. The coarse matrix of the deposit and angularity of the clasts on the surface are dissimilar to the fine-grained matrix and more rounded clasts on the lower surface. The two surfaces probably do not represent one original surface that was separated by faulting. North of Silver Lake the fault crosses Tioga through Tahoe (?) lateral moraines at point $A$ in Figure 1, but does not seem to displace any of them, although colluvium and slumping complicate the geomorphic relationships. Farther to the north, the fault crosses the east face of Mount Wood (Figure 1). Most of the talus wedges that combine to form this slope have gentle concave upward slopes in down slope sections. 
However, some of the older (?) wedges end abruptly with convex upward profiles along the path of the fault, and may be faulted. Also along this section of the fault, a rock-glacial moraine of Tioga age appears to have overridden a preexisting scarp but is itself unfaulted. The relationships here may indicate that the fault has been inactive since Tioga time, but had been active not long before.

A scarp that crosscuts the right-lateral Tahoe moraine at Parker Canyon may have been formed by faulting (Figure 1). Springs flow from its base, and the slope is steep and relatively free of vegetation. The Tioga moraine to the north is unfaulted, and it is difficult to trace the fault into the bedrock directly to the south, but it is collinear with the scarps of the Silver Lake Fault in the colluvial apron of Mount Wood. Upstream from the scarp, Tahoe and Tioga moraines are at approximately the same elevation. Directly next to the scarp but on the down-dropped side, the Tahoe moraine is overlain by a meadow, suggesting sagging or back-tilting next to the fault. Downstream, where the Tahoe moraine is not overlain by meadow, it is about $45 \mathrm{~m}$ below the Tioga moraine. This is peculiar, because in all canyons where both Tioga and Tahoe moraines are unfaulted, Tahoe moraines are as high as or higher than Tioga moraines. The low height of the Tahoe moraine therefore suggests that it is offset, possibly $45 \mathrm{~m}$ [Clark, 1979]. Although it does not crop out alongside the Tioga moraine, the Tenaya moraine crest projects to approximately the same height as the Tioga moraine, except at the Tioga terminus, which is anomalously high. Such a relationship is consistent with either a lack of faulting or very little faulting in the period between Tioga and Tenaya time. The above information was used to construct the slip curve shown in Figure 4. From Tahoe to Tenaya time, the data are consistent with a slip rate of as much as $2 \mathrm{~mm} / \mathrm{yr}$. From Tenaya to Tioga time a low or zero slip rate is suggested. No faulting has occurred since Tioga time.

Both the Silver Lake Fault and the range-bounding fault at Parker Canyon can be projected into the moraines of Bloody Canyon. However, few scarps crosscut these moraines. The 200,000(?)-year-old pre-Mono Basin II moraine [Gillespie, 1982] is probably offset by the range-bounding fault, since it terminates abruptly along the path of that structure. A Sierra-facing slope at the up-canyon end of the Mono Basin right-lateral moraine may be caused by backtilting on the down-dropped side of the range front fault. No fault scarps can be seen in lateral moraines of Tioga through Tahoe ages.

Clark [1979] hypothesized that the low elevation of the Mono Basin moraines relative to the Tahoe moraines was caused by faulting. He noted that the Mono Basin moraines extend down-valley a distance intermediate between that of the Tioga and Tahoe moraines. In most canyons where moraines have down-valley extents similar to one another, their crests are within $15 \mathrm{~m}$ of one another in height, except at termini. At Bloody Canyon, the crests of the Mono Basin moraines are an average of $60 \mathrm{~m}$ below the crest of the Tahoe right-lateral moraine, indicating that faulting between Tahoe and Mono Basin time may have down-dropped the Mono Basin moraines so that later moraines were deposited with crestal elevations considerably higher in a situation similar to that at Parker Canyon. Figure 4 illustrates the possible vertical slip on both Silver Lake and range- bounding faults at Bloody Canyon. Offset of the pre-Mono Basin II moraine is taken as a minimum, since possible offset by the Silver Lake Fault is not included, and since the lower surface of the scarp may not be till but colluvium. As the figure shows, both faults have been inactive at least since Tahoe time, even though they may have had a slip rate of about $0.8 \mathrm{~mm} / \mathrm{yr}$ between Tahoe and pre-Mono Basin II time.

Both the Silver Lake Fault and the range front fault appear to die out north of Bloody Canyon. Small Tioga and Tahoe moraines at Gibbs Canyon (Figure 1) appear to be unfaulted along the path of the Silver Lake Fault, even though there is a bedrock escarpment and 750,000-year-old Sherwin till is either faulted or tilted [Kistler, 1966]. Tahoe moraines at Lee Vining Canyon are unfaulted along the path of the range-bounding fault.

Mono Lake Fault. Offsets of Tahoe and Mono Basin moraines by the Mono Lake Fault at Lee Vining Canyon are not measurable because Tioga-stage lacustrine terraces have covered the down-dropped sections of the moraines; however, since they end abruptly along the path of the fault, they are probably offset several tens of meters. One of the lacustrine terraces is displaced $4 \mathrm{~m}$ along the fault scarp, which trends obliquely to terrace risers at the canyon mouth (Figure 5). To the south of Lee Vining Canyon, the scarp does not crosscut a prominent 13,000-year-old terrace at about $2090 \mathrm{~m}$ [Lajoie, 1968; Lajoie and Robinson, 1982], suggesting that the offset terrace is greater than 13,000 years old.

A number of Pleistocene alluvial fans and lacustrine terraces along the shore of Mono Lake between Lee Vining and Lundy Canyons are truncated by scarps. Many of these scarps are arcuate and exhibit a large displacement over a short map length, suggesting that they are the head scarps of landslides or slumps. However, the apparent lack of slide deposits suggests that they may have been down-dropped by more recent faulting.

Two sections of this portion of the range front merit special attention. One scarp, at point $\mathrm{E}$ in Figure 1, has a small and relatively constant offset along its length. It was probably formed by a fault that displaces late Pleistocene terraces. It can be projected to the south into Mono Lake, and further still, into a fault that Pakiser [1976] defined in refraction profiles underneath the Pleistocene delta of Lee Vining Creek. It is possible, then, that a major range front fault lies to the east of the current range front at Lee Vining Canyon. North of point E, the path of the Mono Lake Fault crosses the Pleistocene delta of Mill Creek. Two possible fault scarps crop out along this section of range front. However, the scarps may well be wave-cut cliffs formed during two of the higher lake stands, since they crop out at approximately the same elevations as two prominent lacustrine terraces. The apparent lack of faulting between point $\mathbf{E}$ and Lundy Canyon suggests that post-Tioga faulting, which is so prominent at Lundy Canyon, may die out rapidly to the south, before resuming at point $E$ and continuing southward.

The Mono Lake Fault scarp at Lundy Canyon has long been appreciated for its pristine appearance [Russell, 1889]. The fault displaces Tioga stage moraines $21 \mathrm{~m}$ across a scarp that is clearly visible in ground moraine and outwash as well as in lateral moraines. Mono Basin and Sherwin moraines outboard of the Tioga moraines are buried on the basin side 


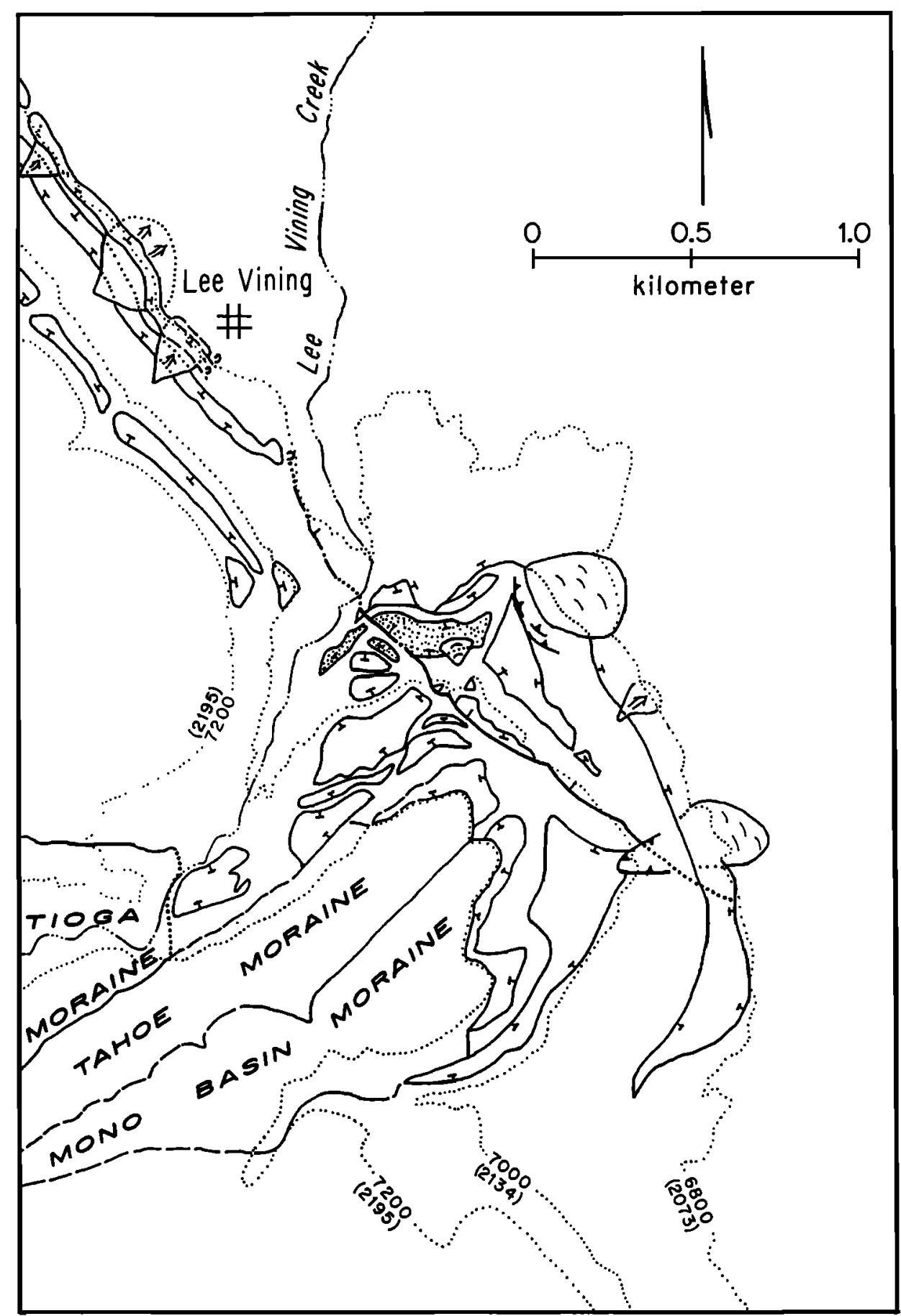

Fig. 5. Offset terraces at the mouth of Lee Vining Canyon. Terraces are marked by contacts with "T's" on terrace treads. Alluvial fans (arrows), colluvial fans (crescents) and head scarps (serrated lines) are also shown. Elevations in meters are in parentheses. Offset Tioga recessional terrace is shown in stipple. The fault does not seem to break the 13,000-year-old terrace just above $2073 \mathrm{~m}$, suggesting that most recent offsets occurred prior to 13,000 years ago.

of the frontal fault. Therefore, the vertical separations between their crests and the valley floor of 150 and $270 \mathrm{~m}$, respectively, place constraints on the minimum amount of offset. The data shown in Figure 4 suggest that range front faulting at Lundy Canyon may have been continuous and substantial throughout late Quaternary time, with a slip rate of 1 to $2 \mathrm{~mm} / \mathrm{yr}$.

Intrabasinal Faults. Several faults within the basin north of June Lake appear to break late Pleistocene drift, an example of which is the one approximately $3 \mathrm{~km}$ east of Grant Lake (Figure 1) that offsets a Tahoe-stage lateral moraine down to the west. The fault consists of a series of low, en echelon scarps, suggesting that its slip rate, as well as that on the fault that probably breaks Tioga and Tenaya till at point $\mathrm{C}$ in Figure 1, is much lower than the range front slip rate. 
Other faults north of June Lake do not seem to break late Pleistocene material; for example, a northeast trending scarp appears to crosscut Tioga and Tenaya moraines at the northeastern edge of Grant Lake. However, because the boulder fields atop the crests of the Tioga moraines drape the scarp instead of being displaced along it, the fault movement probably predates the Tioga glaciation. The Tenaya moraine terminates at the scarp, perhaps because a prominent Tioga-stage terrace cuts the moraine, and not because of faulting.

Some scarps within the basin are probably associated with volcanic activity. East of $F_{3}$ at June Lake, a small hill is uplifted along northeast and north trending faults (point B in Figure 1). Some of the short scarps on the faces of the hill are probably quite young, judging from their rather steep slopes. Part or all of the offset on these faults may have been caused by dikes underlying the southern part of the Mono Craters. This is especially true of the fault that was the guiding fracture for the eruption of the craters at the southern end of the chain. This fault offsets Bishop Tuff at least $30 \mathrm{~m}$ where it has been exposed in the southernmost crater. Based on relationships near point $B$, it is apparent that part of the offset on fault $F_{3}$ at June Lake may have been caused by magmatic intrusion near the southern end of the Mono Craters. Along the southern and northern shores of Mono Lake, and on the islands within the lake, numerous scarps and lineaments show that deformation has occurred near the center of Mono Basin. The largest amounts of deformation are probably associated with volcanic uplift or extrusive volcanism of the islands of Mono Lake or the Mono Craters. Most of the scarps have been modified by lacustrine processes, making it difficult to measure slip rates.

Faults on the eastern edge of Mono Basin. Range front faults along the southwestern edge of Cowtrack Mountain offset Bishop Tuff no more than about $90 \mathrm{~m}$. This implies a relatively low slip rate if it has remained constant since the Bishop Tuff was deposited 710,000 years ago. To the north along the range front, a paucity of late Quaternary deposits renders it difficult to say whether the range front has been active in late Quaternary time.

\section{HisTORY OF CONSTRUCTION OF THE MONO CRATERS}

Before estimating the timing and magnitude of deformation associated with the Mono Craters, it is important to consider the shapes of intrusions which have fed them. If the intrusive bodies are dikes, then a relatively straightforward way to relate faulting and volcanic deformation is by comparing extension rates due to each process. Sieh and Bursik [1986] showed that the last eruption from the Mono Craters had a dike source that extended for $6 \mathrm{~km}$ from North Coulee to Panum Crater (Figure 6). Miller [1985] and Fink [1985] showed that the products of the latest eruptions of the Inyo Craters may have issued from an 11-km-long dike that extended from the southwestern perimeter of Long Valley Caldera to the Inyo Domes. As shown in Figure 6, flow foliations and lineaments on other domes within the Mono Craters suggest that these were also erupted from dikes. Finally, the edifice of the Mono Craters is elongate northsouth. The above data suggest that dike intrusion has occurred repeatedly over the lifetime of the Mono Craters.
Therefore, since extension rates related to faulting and volcanism can be directly compared, the task is to estimate dike intrusion rates underneath the Mono Craters.

In our analysis, we infer the spatial and temporal distribution of dikes by using surficial information. To understand spatial distribution, we have divided the Mono Craters into segments according to the number of dikes that may underlie each segment. We assume that the number of dikes in each segment is constant along its length, but varies from segment to segment. We have used available ${ }^{14} \mathrm{C}$ and hydration rind data to constrain the temporal distribution of dikes that have fed the Mono Craters. Ages of some of the domes are known much more precisely than is needed for present purposes - because we seek to compare dike intrusion with faulting rates, we need only resolve the timing of intrusions to the degree to which we have resolved the timing of fault offsets. So, although some eruptions and their dike intrusions have been dated precisely with ${ }^{14} \mathrm{C}$, the data will be used to relate intrusion ages to the more poorly constrained glacial chronology that was used to determine fault slip rates.

\section{Ages of the Volcanoes of Mono Basin}

Late Pleistocene volcanism appears to have started in the Mono Basin less than 40,000 years ago. The oldest eruptions are recorded in the beds of Pleistocene Lake Russell (Mono Lake) and at the June Lake cinder cone. Lajoie [1968] studied a section of lacustrine silt beds that are from 12,000 to 36,000 years old, which crop out throughout the basin and which he named the Wilson Creek Formation. Lajoie [1968] and Lajoie and Robinson [1982] found that all rhyolitic ash layers in the Wilson Creek Formation were chemically similar to the domes of the Mono Craters. However, none of the ash layers sampled by Lajoie [1968] in older lake beds that crop out on Paoha Island were of Mono Craters affinity. Lajoie's data therefore suggest that no rhyolitic volcanism at the Mono Craters is older than 36,000 years. The basalt of June Lake is probably older than Tioga till but younger than Tenaya till [Bursik, 1988]. Since the Tenaya glaciation is tentatively thought to have occurred 35,000 to 45,000 years ago, the basalt of June Lake erupted between about 40,000 years and 20,000 years ago.

Where are the domes that correlate to the ash layers of the Wilson Creek Formation? Although Mono Craters rhyolitic volcanism seems to have initiated about 40,000 years ago, only one of the currently exposed domes may be more than about 20,000 years old, as discussed in detail below. The exposed domes, however, constitute only half the total $8.5-\mathrm{km}^{3}$ volume of the Mono Craters. Therefore, most of the 19 rhyolitic ash beds in the Wilson Creek Formation were erupted in association with domes that are now buried. Most of the buried domes probably lie underneath the central section of the Mono Craters, near Crater Mountain (Figure 6), because much of the unexposed volume of the edifice lies in that section.

The ages of most of the exposed domes and flows of the Mono Craters are constrained by obsidian hydration rind data from Wood [1977]. The obsidian hydration rind dating method consists of measuring the thickness of rinds of hydrated glass, which form on all obsidian fragments as atmospheric or soil moisture diffuses into the glass. A suite of hydration rind thicknesses measured on different domes can 


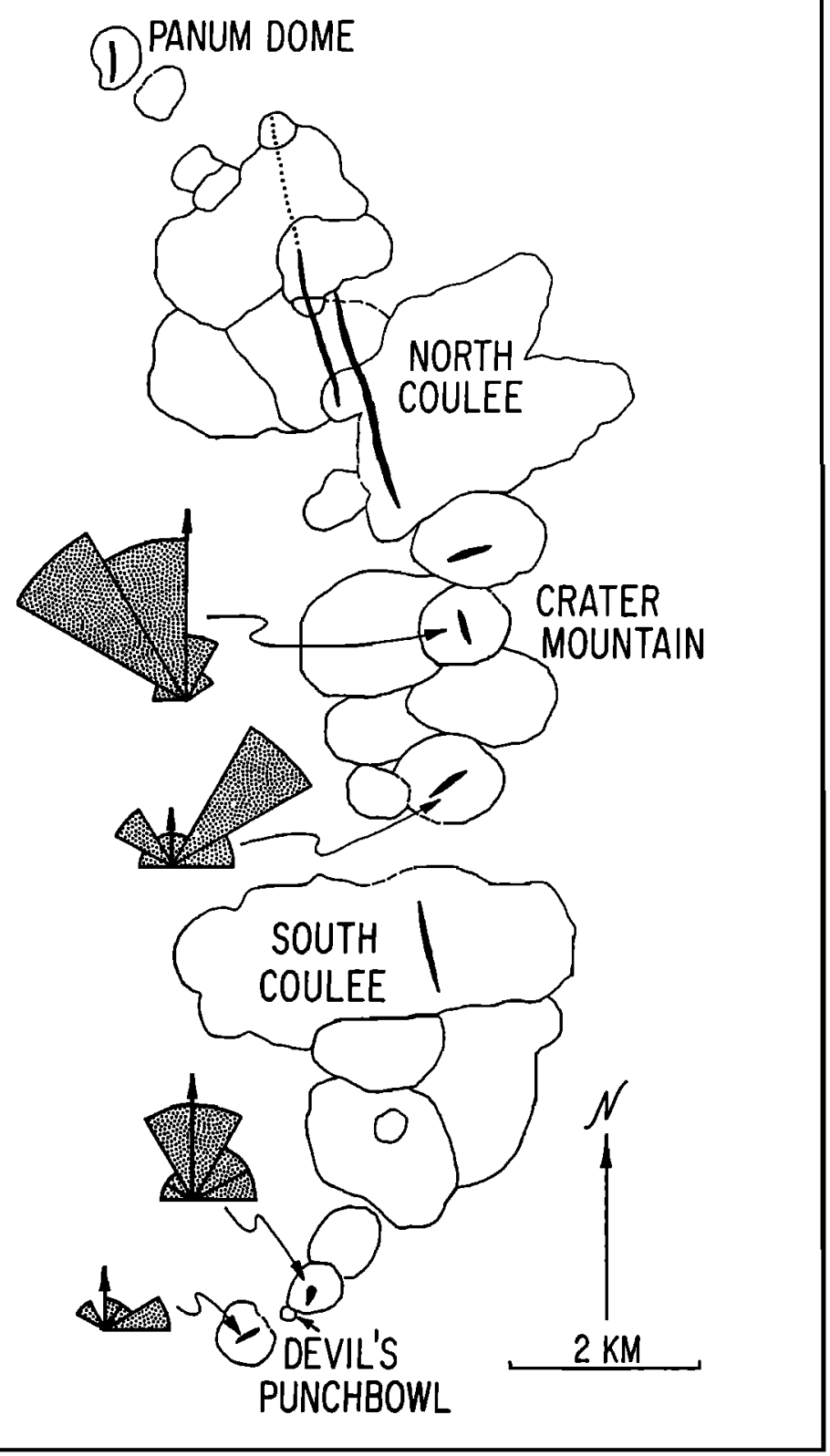

Fig. 6. Probable trends of dikes underneath Mono Craters. Data for the dome north of Crater Mountain are from Kelleher [1986], for North Coulee and Panum Dome from Sieh and Bursik [1986], and for South Coulee from Loney [1968]. Rose diagrams show strikes of flow foliations in domes mapped for this study. Dikes are schematically depicted as tapering solid lines inside the flows.

be transformed to ages by calibration against one measurement of thickness for which an absolute age is also available. If an absolute date is not available, then the hydration rate must be assumed for calibration. Because Wood [1977] calibrated his hydration rind thicknesses with the less satisfactory method of assuming a hydration rate, we have recalibrated his hydration rind curve by tentatively correlating dome 11 to a 13,320-year-old ash layer in the Wilson Creek Formation [Denham and Cox, 1971]. The dome and the ash bed have a similar, distinctive phenocryst assemblage [Kelleher, 1986; M. Fahnestock, personal communication, 1988]. The recalibrated hydration rind versus age curve is shown in Figure 7.
As a confirmation of the validity of the recalibration, the new hydration rind curve fits new ${ }^{14} \mathrm{C}$ ages on some of the younger domes and a gap in deposition of tephra recorded in the sediments of Black Lake [Batchelder, 1970] better than does the curve of Wood [1977]. Four domes sampled by Wood [1977] which comprise the North Mono eruption of 605 \pm 20 yr B.P. ( $\pm 2 \sigma$ [Sieh and Bursik, 1986]) have a mean hydration rind age of $900 \pm 400$ years using the new calibration, and a mean age of $1500 \pm 700$ using Wood's calibration $( \pm 1 \sigma)$. Dome 22 has a hydration rind age of $1800 \pm 300$ based on the new calibration or $3200 \pm 500$ based on the old. New ${ }^{14} \mathrm{C}$ ages for tephra layers correlative to this dome suggest it was erupted about 1400 years ago. A gap in the deposi- 


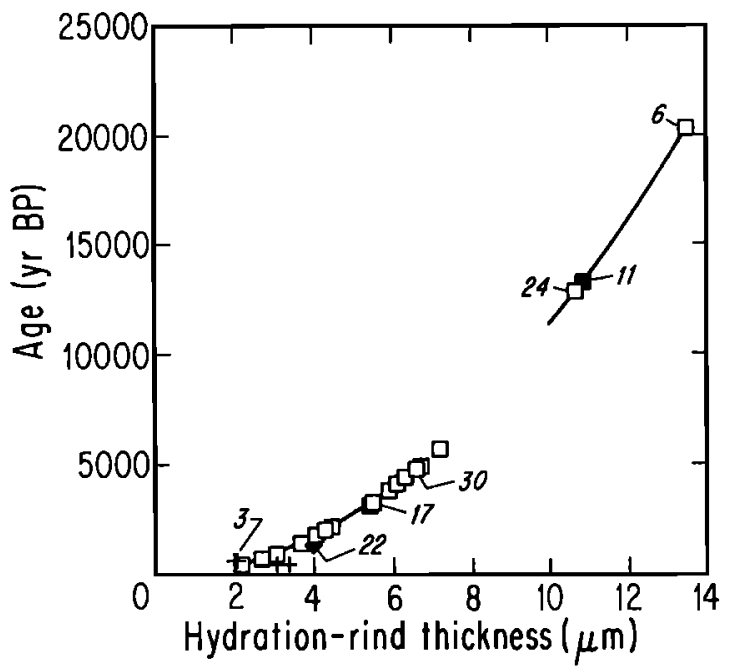

Fig. 7. Ages of the Mono Craters determined by the hydration rind method. Hydration rind thicknesses are from Wood [1977]. Numbers are dome numbers shown in Figure 8. Only selected domes are numbered, including Panum Dome (dome 3), South Coulee (dome 22), Crater Mountain (dome 17), and the southernmost dome of the chain (dome 30). Crosses are domes that correlate to radiocarbon-dated $605 \pm 20$-year-old tephra [Sieh and Bursik, 1986], and the diamond is dome 22, which correlates to a 1400-year-old tephra. The curve is calibrated with dome 11 (solid box) and is drawn through hydration rind data from domes that are undated with radiocarbon (open boxes). The gap in deposition of Mono Craters tephra at Black Lake is shown by the gap in the hydration rind curve. Typical error bars for hydration rinds are $\pm 0.3 \mu$ ( $\pm 1 \sigma$ measurement precision).

tion of Mono Craters ash at Black Lake, east of the Mono Basin, occurs between layers with (uncalibrated) ${ }^{14} \mathrm{C}$ ages of $11,350 \pm 350$ and $5230 \pm 110$ yr B.P. [Batchelder, 1970]. Using Wood's calibration, many domes have ages which fall within this time gap. Using the new calibration, a gap in hydration rind ages of domes occurs between about 5800 and 13,000 years ago. We conclude that the new hydration rind calibration yields reasonable ages for the domes of the Mono Craters.

The hydration rind curve shown in Figure 7 suggests that only dome 6, at the northern end of the chain, may be older than the Tioga glaciation. Dome 24 may have been erupted at about the same time as dome 11 , that is, at the time of maximum Tioga glaciation. All other currently exposed domes from which Wood [1977] measured hydration rinds seem to be Holocene in age. One dome that Wood [1977] did not sample is, like dome 6, probably quite old. Dome 12 is cut by a 12,000- to 14,000-year-old shoreline of Lake Russell [Lajoie, 1968; Lajoie and Robinson, 1982], is chemically unevolved [Kelleher, 1986], and, therefore, probably predates the Tioga glaciation.

A number of volcanic edifices lie outside the Mono Craters proper (Figure 1). The ages of Black Point and the volcanic islands of Mono Lake are well constrained by ${ }^{14} \mathrm{C}$-dated ash layers. Ash which erupted from Black Point occurs just above a ${ }^{14} \mathrm{C}$-dated ostracod-bearing horizon in the Wilson Creek Formation [Denham and Cox, 1971] and is approximately 13,300 years old and late Tioga in age. Stine [1987] showed that the oldest part of the Mono Lake Islands, the platform of Negit Island, is older than $2000 \pm 200{ }^{14} \mathrm{C}$-yearold ash that mantles it. No older ash overlies it. The rest of Negit Island and the volcanoes on Paoha Island are not overlain by the $2000{ }^{14} \mathrm{C}$-year-old ash and therefore postdate it. All of the Inyo Craters appear to be late to middle Holocene in age [Miller, 1985].

\section{Ages of Domes in Segments}

The maximum ages of domes in all segments except segment 5 (Figure 8) are probably well represented by domes currently exposed, so we give only a brief summary of the age of initiation of volcanism in most segments. All domes in segments 1 to 3 are well exposed, and most have Holocene hydration rind or ${ }^{14} \mathrm{C}$ ages [Miller, 1985] (Figure 7). Segment 4 contains dome 24, which is about 13,000 years old, and the segment is therefore considered to have formed completely from Tioga time to the present. Segment 6 contains the dacitic dome 12, and, as discussed above, has probably been active since Tioga to Tenaya time. Segment 7 includes dome 6 , which has a hydration rind age of about 20,000 years. We estimate the segment to have become active in Tioga to Tenaya time. Segment 8 contains only two domes, the oldest of which (dome 4) may have been erupted during the same event as domes 7 and 8 . Dome 4 is overlain by 600 -year-old tephra but not by any older tephra. It

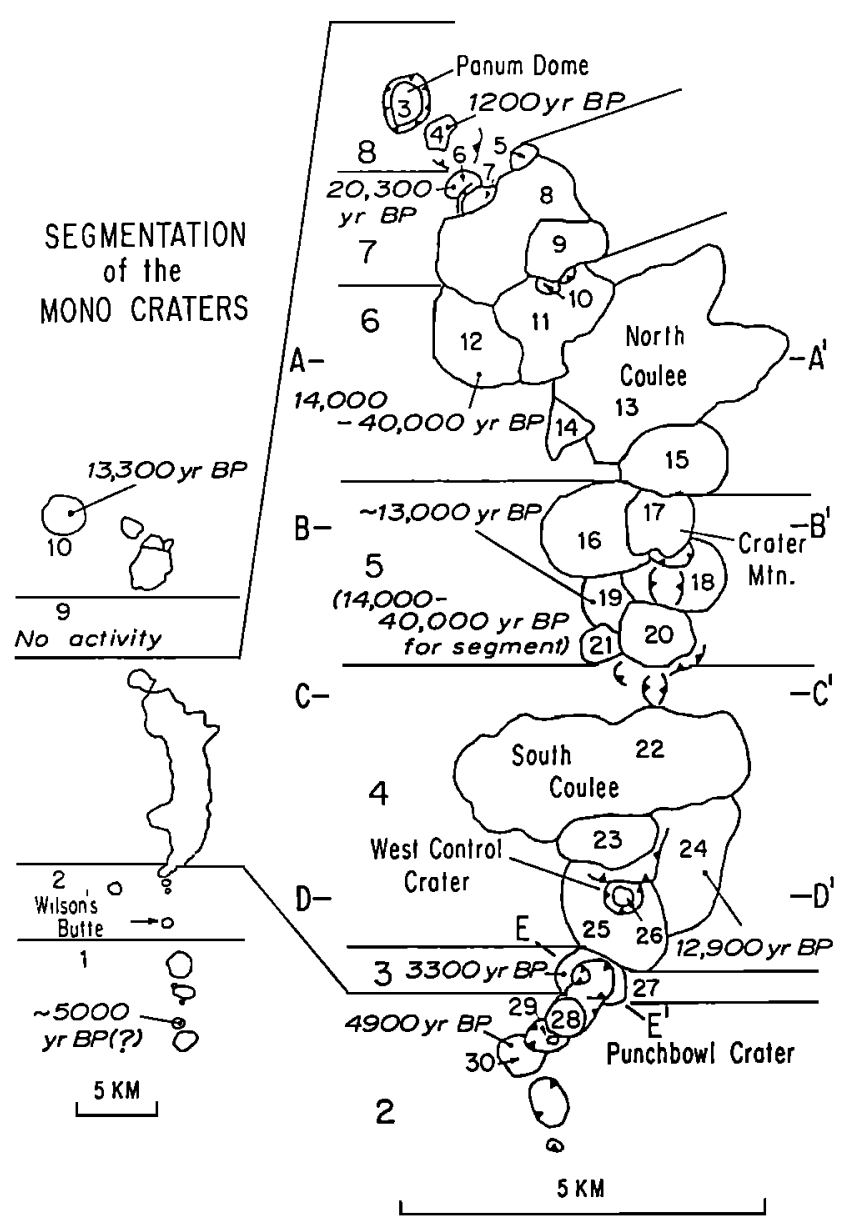

Fig. 8. Segmentation of the Mono Craters according to the hypothesized number of underlying dikes. Cross sections are shown in Figure 9. Segments are chosen so that the number of dikes along the trend of each is constant. Dividing the volcanic features into segments allowed the calculation of rates of extension caused by dike intrusion. 
may correlate to a $1200 \pm 200$ year old pyroclastic flow in Rush Creek. All volcanism in segment 8 has therefore occurred from Tioga time to the present. No volcanism has been known to occur in segment 9 (Figure 8), although some crater like forms can be seen in bathymetric maps made by Pelagos Corporation [1987]. The oldest volcanism in segment 10 (Figure 8) is the 13,300-year-old Black Point volcano, and therefore all dike intrusion in the segment occurred from Tioga time to the present.

The age of segment 5 is probably underestimated by the age of the oldest dome in that segment, because of burial of a large number of older domes by the younger, exposed domes. The oldest dome in segment 5 may be dome 19. It is thickly mantled with ash and petrographically similar to domes 11 and 24 [Kelleher, 1986], both of which are about 13,000 years old. Since dome 19 crops out rather high in the edifice of the central Mono Craters, it probably overlies at least two older domes (Figure 9). Therefore, eruptions from segment 5 probably initiated between Tioga and Tenaya time, and perhaps earlier.

The general pattern of latest Quaternary volcanism in the Mono Basin can be summarized as follows: Initial eruptions occurred in the central and north central parts of the Mono Craters (segments 5 and 6) and at June Lake between Tioga and Tenaya time. During maximum Tioga time, eruptions occurred at Black Point and began in the south central Mono
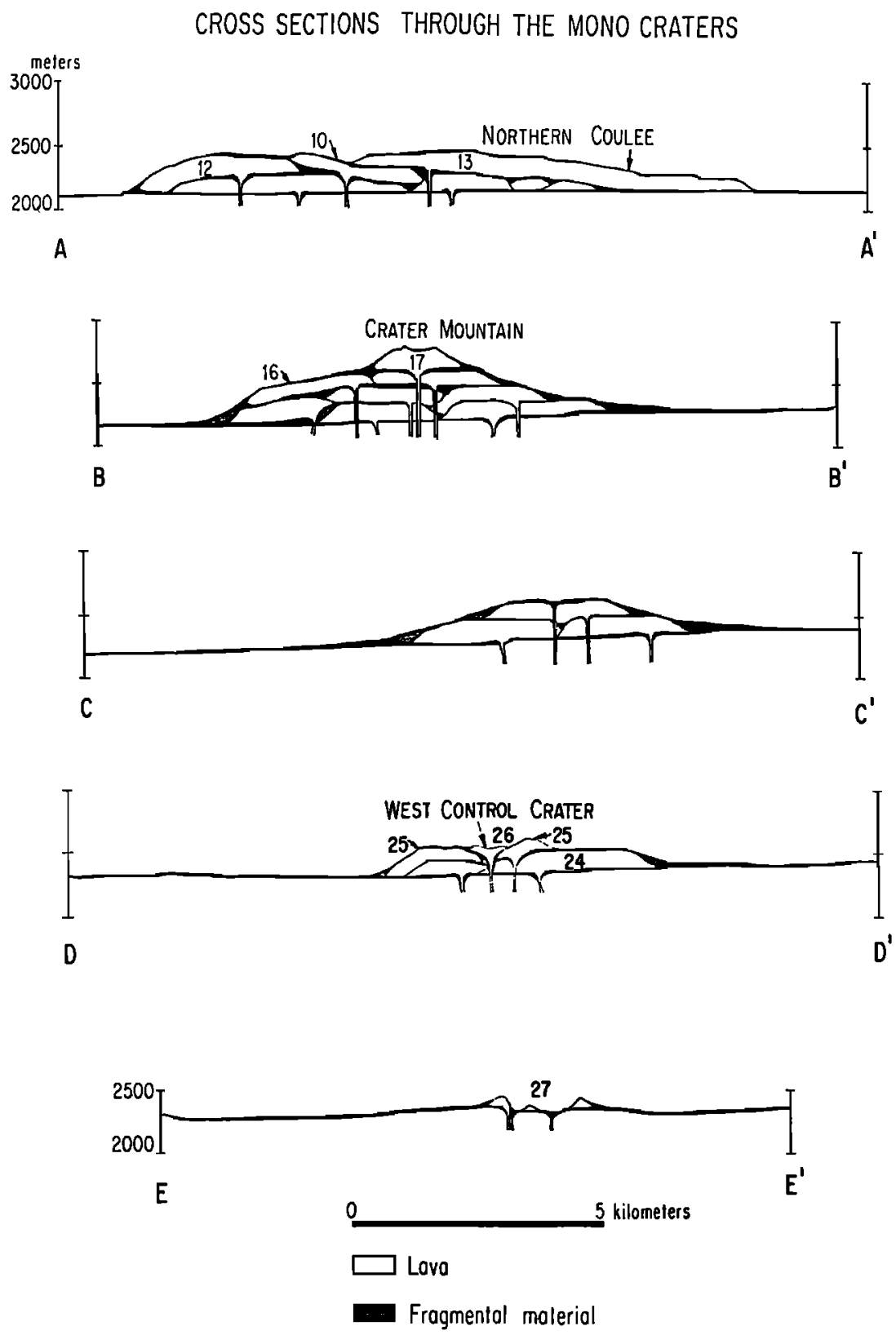

Fig. 9. Cross sections through the Mono Craters. Lines of section are shown in Figure 8. Number of dikes underlying segments with buried domes was estimated by filling the cross sections with domes of average crosssectional area. Using this technique, the greatest density of dikes was found underneath segments 5 and 6 (cross sections $\mathbf{A - A ^ { \prime }}$ and $\mathbf{B}-\mathbf{B}^{\prime}$. 
Craters (segment 4). In Holocene time, volcanic activity has extended south to the Inyo Domes and north to the islands of Mono Lake.

\section{Number of dikes}

There is no simple way to determine the number of dikes that are intruded underneath the Mono Craters. Bacon [1982] assumed that the volume of domes erupted in the Coso Volcanic Field during a given time interval was proportional to the thickness of dikes and therefore to extension. Two approaches, both of which differ from that of Bacon [1982], will be used here to estimate the number of dikes, depending on the outcrop pattern of domes in the segment under consideration. The first approach is based on the assumption that the number of dikes is proportional to the cross-sectional area of the Mono Craters edifice, and is applicable to those segments in which buried domes probably exist. There is an average dome size for the Mono Craters - about the size of Panum Dome or Crater Mountain (Figure 8). If cross-sectional slices are made through the Mono Craters, then a certain number of average-size domes will be intersected by each slice. If a dike is connected to each dome in the cross section, then the extension caused by dike intrusion in that cross section can be estimated, assuming a certain thickness for each dike. This is the method illustrated in Figures 8 and 9. Figure 8 is a map view showing exposed domes and positions of cross sections in Figure 9. Figure 9 shows the cross sections filled with average-size domes and fragmental debris to satisfy outcrop patterns and subsurface data, which consist of three logs of exploratory shafts drilled near South Coulee for the Mono Craters Tunnel of the Los Angeles Department of Water and Power. These logs show that there is up to $100 \mathrm{~m}$ of fragmental material on the flanks of the Mono Craters [Berkey, 1935]. Also shown in Figure 8 are the numbered segments of the Mono Craters. The segments encompass the length along the craters over which the lettered cross sections are thought to provide reasonable estimates of the number of dikes. So, segment 5 (cross section $B-B^{\prime}$ in Figure 9) is that under which we have estimated there to be eight feeder dikes. Segment 4 is constrained by two cross sections $\left(C-C^{\prime}\right.$ and $\left.\mathrm{D}-\mathrm{D}^{\prime}\right)$, both of which can be filled with four averagesize domes. Segment 6 may be underlain by five dikes (cross section $\mathbf{A}-\mathbf{A}^{\prime}$ ).

A second approach was used to estimate the number of dikes in the remaining segments. In these segments, all domes are currently exposed, so cross sections were not useful. In some of these segments, the ages of eruptive events during which separate domes were extruded are known. In others, reasonable assumptions about the number of events of dome formation and dike intrusion were made based on available chronological and petrological data as well as stratigraphic relationships between the domes and dated tephra layers. The following is a summary of the estimated number of dikes in each of these segments. Segment 1 contains domes which may have been formed during only two separate intrusion events, if the small dome at Glass Creek and "Sampson's Dome" [Sampson, 1987] are the same age as the North Deadman Dome. It seems reasonable that these domes were erupted during the same episode since, as Miller [1985] showed, all other domes in segment 1 formed during one eruptive event about 600 years ago. The distances over which the domes of the two generations crop out along strike overlap; thus we estimate that two dikes underlie the entire segment. Segment 2 also contains domes which formed during at least two eruptions. Wilson's Butte is 1350 to 1200 ${ }^{14} \mathrm{C}$ years old [Miller, 1985]. The domes at the southern end of the Mono Craters (domes 28 to 30 ) are petrologically similar to one another, and dome 30 has an obsidian hydration rind age of 4,900 \pm 500 years. Therefore, there may have been only two eruptive events in this segment 1300 years ago and 4900 years ago. The craters between Wilson's Butte and dome $\mathbf{3 0}$ may have formed during either of these events. Although the domes and craters of this segment formed during at least two events, the ranges over which the domes of the separate events crop out do not overlap, so we estimate that the segment has been extended by only one dike thickness in two distinct extensional events. Wilson's Butte is underlain by one dike, and the southern Mono Craters are underlain by another. Segment 3 (cross section E- $\mathrm{E}^{\prime}$ in Figure 9) consists of one dome that has been cratered by two more recent events and may therefore be underlain by three dikes. Segment 7 includes domes of three distinct ages. Domes 5 and 9 formed during the North Mono eruption of $600 \mathrm{yr}$ B.P. [Sieh and Bursik, 1986]. Domes 7 and 8 are both overlain by tephra from the 600-year-old eruption, but are not overlain by any older tephra. They both may be correlative with the $1200 \pm 200$ year old pyroclastic flow in Rush Creek. Early explosive phases of the eruption associated with domes 7 and 8 blasted through part of dome 6 in the north and through part of dome 12 in the south, so the outcrop areas of domes formed during three separate eruptions overlap, and hence three dikes may underlie this segment. Segment 8 contains only two overlapping domes, and therefore two dikes may underlie it. Segment 9 contains no known volcanic edifice, so no dikes underlie it. In segment 10 , the dikes that fed Black Point and Negit Island trend approximately orthogonal to the overall trend of the volcanic features. If the intrusion which underlies Paoha Island [Pakiser, 1976] is an elongate body between the crater at the south end of the island and the tuff ring in the northeastern corner, then the Paoha Island intrusion also trends orthogonal to the overall trend of the volcanoes. Therefore, we have considered each edifice separately, because there are probably not dike-filled fractures at depth which link the vents, as is the case in other segments. Black Point seems to be the product of a single dike; Paoha Island may be the product of two dikes, and Negit Island may be the product of up to three overlapping dikes [Stine, 1987].

Since it is off the trend of the other volcanoes, we have not assigned the June Lake cinder cone to a numbered segment. A graben north of the cone, collinear with $F_{1}$ (Figure 3), may be the fissure from which it erupted. The fissure has been filled with glacial outwash and pyroclastic material since its formation.

Numbers and ages of dikes are summarized in Table 2. As suggested above, segment 5 contains the greatest number of dikes. Since it is reasonable for the greatest number of dikes to overlie the source of magma, the large amount of extension in segment 5 is consistent with the finding of Achauer et al. [1986] that a body of seismically slow material (perhaps a magma chamber) lies beneath it. Note also in Table 2 that the number of dikes in segments 6 through 8 had to be apportioned between Tenaya to Tioga time, and Tioga time to the present. The apportionment of dikes in each period 


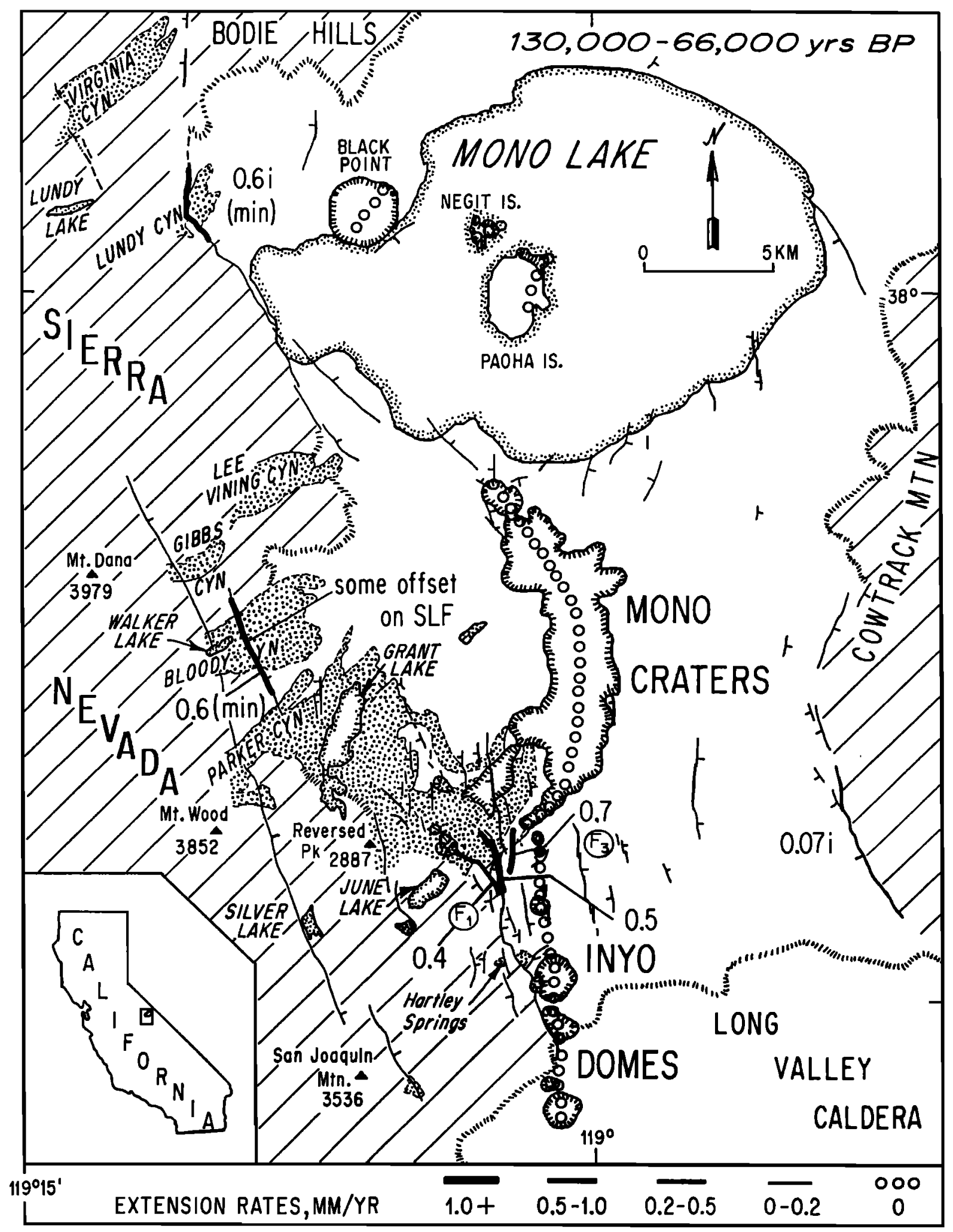

Fig. 10a

Fig. 10. Extension rates in time slices; i is interpolated from slip rate measured over a time interval longer than that depicted; $e$ is extrapolated from later time interval based on air-photo interpretation. Slip rates at Hartley Springs are based on proportionally dividing slip into intervals as at June Lake. (a) Mono Basin to Tahoe time, 130,000 to 66,000 yr B.P. Data are compatible with a constant slip rate along the entire Sierra Nevadan range front in the Mono Basin, and a lack of volcanic activity. (b) Tahoe to Tenaya time, 66,000 to 40,000 yr B.P. Range front faulting has ceased at Bloody Canyon, but has continued along the rest of the range front faults. There is also no volcanism in this time interval, except perhaps in the central segment of the Mono Craters (queried). (c) Tenaya to Tioga time, 40,000 to 14,000 yr B.P. Faulting at Parker Canyon as well as at Bloody Canyon has now ceased, but has continued along the Mono Lake Fault and the Hartley Springs Fault. Dikes intrude underneath the central and northern segments of the Mono Craters and underneath the cinder cone at June Lake. (d) Tioga time, 14,000 yr B.P., to the present. Although faulting at Lundy Canyon has continued at typical range front rates, extension rates are lower at Lee Vining Canyon and at June Lake. Extension from Lee Vining Canyon south to the Inyo Domes is largely taken up by dikes. There is also activity on a west-northwest trending group of northeast trending faults and dikes from Paoha Island to Black Point. 
TABLE 2. Dike Extension Rates in Crater Segments

\begin{tabular}{lccc}
\hline & \multicolumn{3}{c}{ Extension Rate, $\mathrm{mm} / \mathrm{yr}^{a}$} \\
\cline { 2 - 4 } Crater Segment & Minimum & Best & Maximum \\
\hline 1 & 0.3 & 1.1 & 3.8 \\
2 & 0.1 & 0.6 & 1.8 \\
3 & 0.4 & 1.7 & 5.5 \\
4 & 0.4 & 2.3 & 7.3 \\
5 & 0.6 & 1.6 & 4.7 \\
Tenaya-Tioga & 0.4 & 1.2 & 6.2 \\
Tioga-present & 0.6 & 2.3 & 7.3 \\
6 & 0.3 & 1.0 & 2.9 \\
Tenaya-Tioga & 0.2 & 0.6 & 3.1 \\
Tioga-present & 0.4 & 1.7 & 5.5 \\
7 & 0.2 & 0.6 & 1.8 \\
Tenaya-Tioga & 0.09 & 0.3 & 1.5 \\
Tioga-present & 0.3 & 1.1 & 3.6 \\
8 & 0.3 & 1.1 & 3.6 \\
9 & 0 & 0 & 0 \\
10-Negit & 0.4 & 1.7 & 5.5 \\
10-Paoha & 0.3 & 1.1 & 3.6 \\
10-Black Point & 0.05 & 0.1 & 0.5 \\
June Lake cone & 0.03 & 0.08 & 0.4 \\
\hline
\end{tabular}

${ }^{a}$ Minimum, best, and maximum values imply 3, 8, and $20 \mathrm{~m}$ widths, respectively, for silicic dikes and 1,2 and $5 \mathrm{~m}$ for basaltic dikes.

Minimum extension rate, for example, assumes minimum dike width and maximum possible time interval (from Table 1) for calculation.

was based on the cross sections, giving the minimum number of dikes possible to the Tenaya to Tioga period because there seems to be an increase in the rate of Mono Craters volcanism through time [Wood, 1984]. Although Table 2 includes only uncertainties in dike thickness (discussed in the next section), cross sections $A-A^{\prime}$ and $E-E^{\prime}$ give some idea of possible uncertainties in dike number estimates. If one or more of the buried flows under segment 5 has the same area as North Coulee in cross section $\mathrm{A}-\mathrm{A}^{\prime}$, then the number of dikes is overestimated. On the other hand, if some dikes did not breach the surface and formed explosion pits instead, as in cross section $\mathrm{E}-\mathrm{E}^{\prime}$, then the number of dikes is underestimated. Errors in the estimates of the number of dikes may therefore be rather large in segments 4 to 6 , perhaps on the order of $50 \%$, because of the lack of exposure. Errors in segments 1 through 3 and 8 through 10 are probably small because of complete exposure.

\section{EXTENSION RATES}

Estimates of range front faulting and dike intrusion rates allow the computation of rates of extension caused by faulting and dike intrusion, displayed in Figure 10, which shows extension rates for different time slices. The maps were constructed by plotting the extension rate averaged over each time interval. Where displacement rates were not available for a particular time slice, rates were averaged over the next longest available interval.

For faults, extension rate was computed by dividing the horizontal component of dip slip for the time interval, assuming a $60^{\circ}$ fault dip, by the best estimate for the length of time in each interval. For dikes, we multiplied the estimated number of dikes in a time interval by average dike width, then divided the result by the length of the time interval. The average width of a silicic dike was assumed to be $8 \mathrm{~m}$, since this is the width of the dike that was intersected by drilling underneath the Inyo Domes [Heiken et al., 1988]. A plausible minimum width is $3 \mathrm{~m}$, based on the considerations discussed by Sieh and Bursik [1986], and the maximum width could range up to $20 \mathrm{~m}$ [Mastin and Pollard, 1988]. Widths of trachyandesitic dikes underneath Black Point and the June Lake cinder cone are estimated to average $2 \mathrm{~m}$ in thickness [Speight et al., 1982], to have a maximum thickness of $5 \mathrm{~m}$, based on the maximum dilation of fissures on Black Point, which may be directly related to dike intrusion, and to have a minimum thickness of $1 \mathrm{~m}$ or less [Speight et al., 1982; Walker, 1986].

Figure $10 a$ illustrates extension rate between Mono Basin and Tahoe time, from 130,000 years ago to 66,000 years ago. Data are available from only the three locales shown, and all data are minima or maxima. However, they are compatible with a constant extension rate along the entire range front in the Mono Basin of approximately $0.6 \mathrm{~mm} / \mathrm{yr}$. There is no evidence for volcanism in the basin during this period.

From Tahoe to Tenaya time, 66,000 to 40,000 years ago, data are more complete than for the preceding interval. Figure $10 b$ shows that these data are compatible with continued extension on the range front in a left-stepping en echelon zone from June Lake to Parker Canyon, and along the Mono Lake Fault. Fault $F_{3}$ at June Lake (shown by open circles) seems to have become inactive, or dies out rapidly to the north before reaching the Tahoe moraine. Tectonic activity seems to have ceased around Bloody Canyon. Some activity is obvious on the intrabasinal faults north of June Lake. The pattern, amount of offset, and sense of motion (down to the west) on these faults suggest that they are secondary features, perhaps related to flexure between the en echelon range front segments at June Lake and Reversed Peak. Currently available data suggest that there was not yet any volcanism in the basin, except perhaps in the central Mono Craters, depending on the age of the poorly constrained Tenaya glaciation [Bursik, 1988] and on the time of initiation of volcanism in segment 5 .

Between Tenaya and Tioga time, 40,000 to 14,000 years ago, faulting seems to have ceased at Parker Canyon, as well as at Bloody Canyon (Figure 10c). Data are consistent with a somewhat lower extension rate along the Hartley Springs Fault, but an increased extension rate along the Reversed Peak Fault, although it still accommodated less extension than other range front faults. Volcanism had certainly begun in the central and northern Mono Craters by this time, with most activity occurring in the central segment. The volcanic activity in the northern Mono Craters may have been localized along a buried range front fault, hypothesized by Pakiser [1976] to underlie this region, which may crop out just north of Panum Dome. The June Lake cinder cone also erupted at this time, possibly from a fissure which followed $F_{1}$ at June Lake.

Figure $10 d$ shows that from Tioga time $(14,000$ years ago) to the present, only one strand $\left(F_{1}\right)$ of the Hartley Springs Fault at June Lake seems to have been active. There has been a decrease in activity on the Reversed Peak Fault and on the intrabasinal faults north of June Lake. Along the Mono Lake Fault, extension has continued at a typical range front rate of $0.9 \mathrm{~mm} / \mathrm{yr}$ only at Lundy Canyon. To the north, a 9-m-high scarp in Tioga till at Virginia Canyon suggests that faulting has continued there at typical rates. Directly south of Lundy Canyon, no faulting seems to have occurred since Tioga time. Still further south, at Lee Vining 


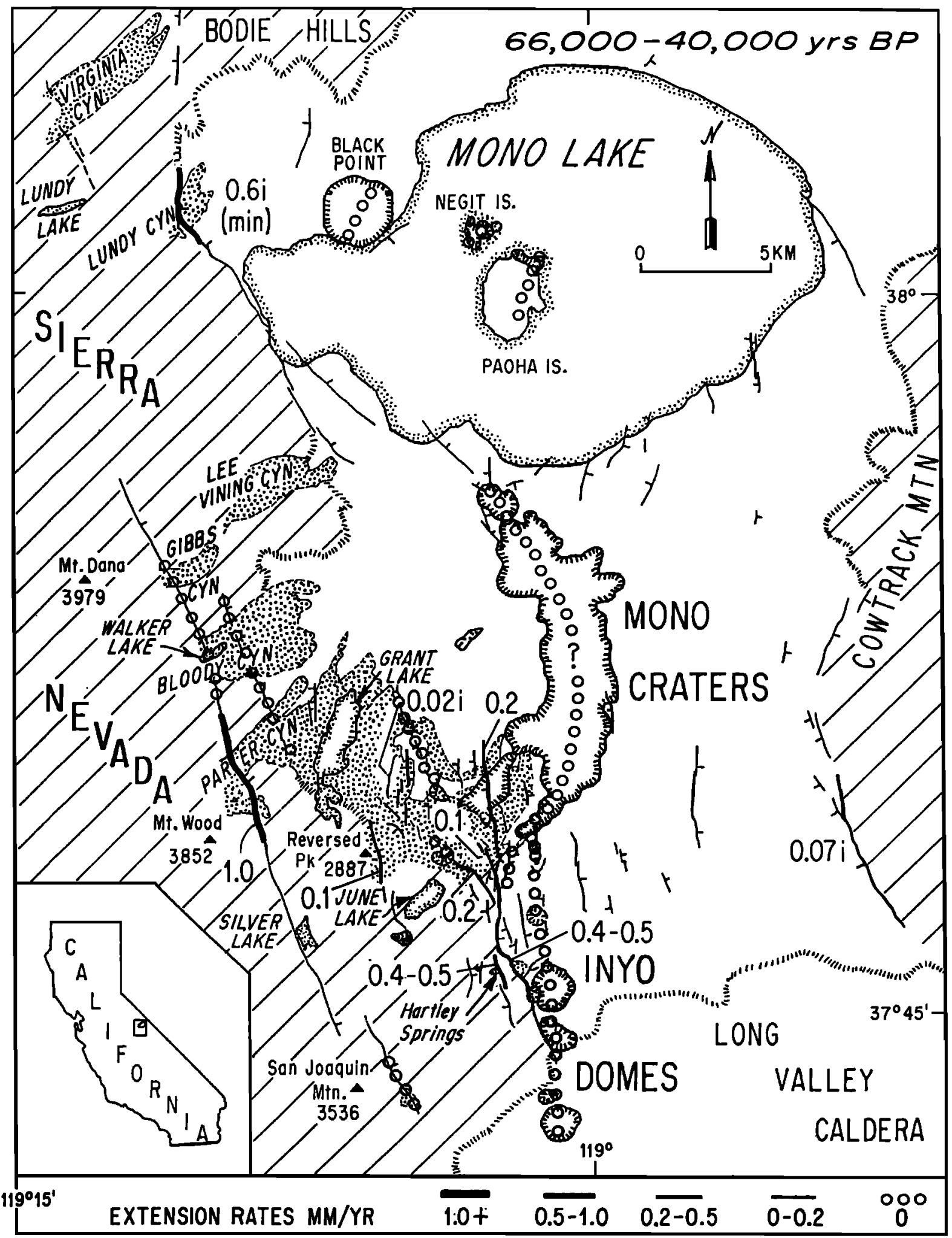

Fig. $10 b$ 


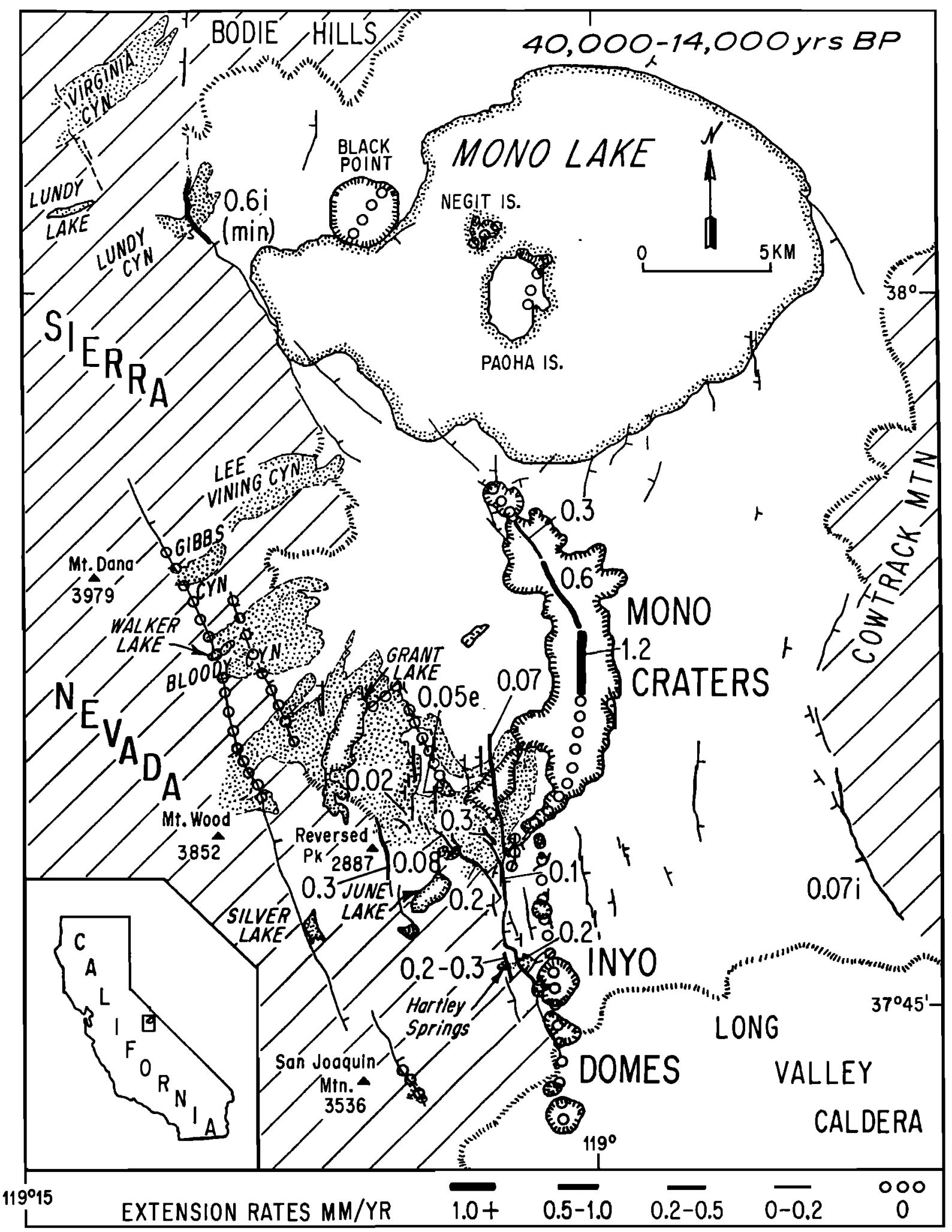

Fig. 10c 


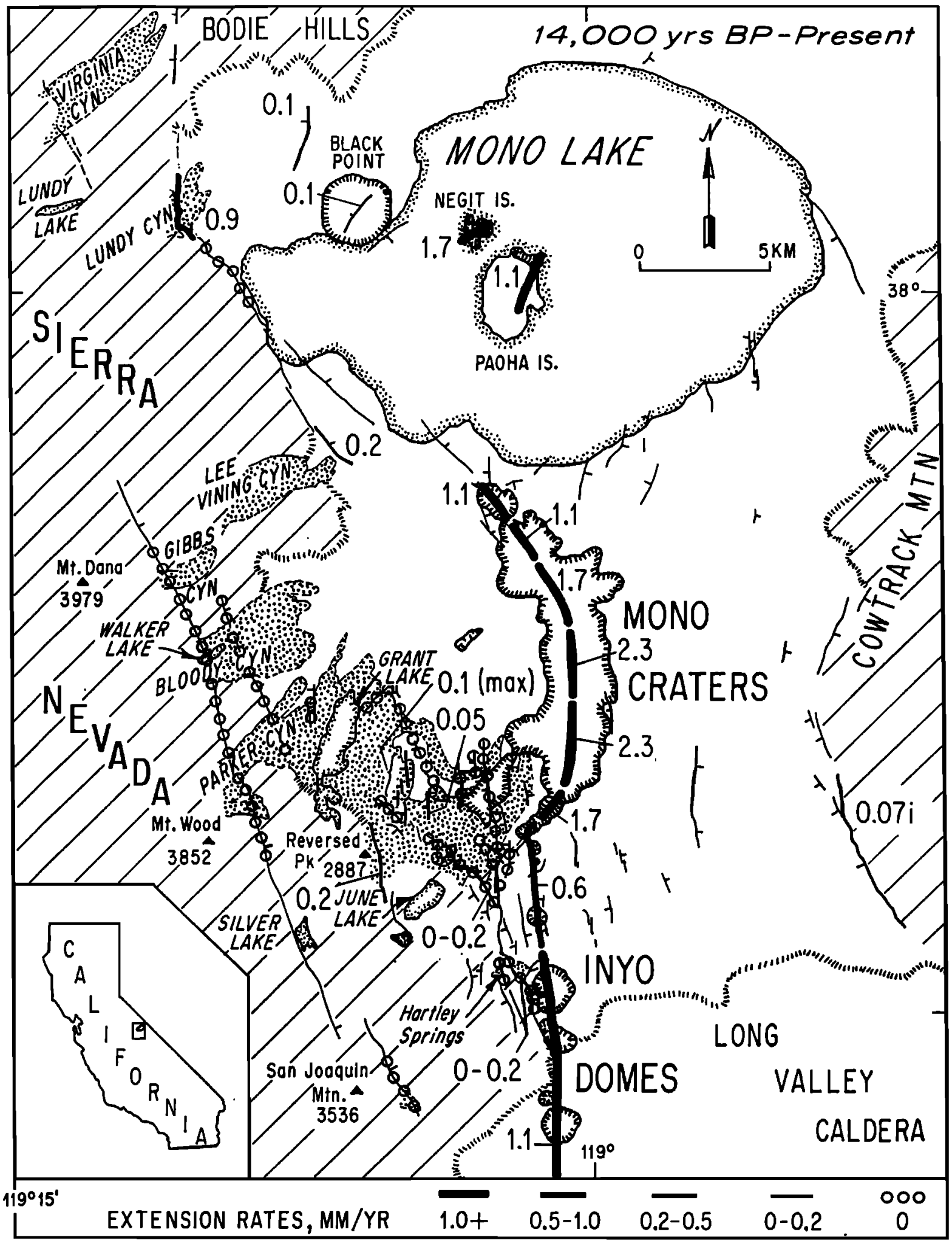

Fig. 10d 
Canyon, the fault has remained active, but at a much lower rate than at Lundy Canyon. In contrast to reduced rates of faulting, volcanic activity has dramatically increased over the preceding period. Activity is concentrated in the central and southern segments of the Mono Craters, but there are high rates of extension due to dike intrusion from Long Valley Caldera to the islands of Mono Lake. Segments 2 and 9 (Table 2) are the least active. The concentrations of volcanic activity may reflect the hypothesized positions of magma bodies under the Mono Lake islands, central Mono Craters, and Long Valley Caldera [Pakiser, 1976; Bailey, 1982; Sanders, 1984; Achauer et al., 1986].

\section{DiRECTION OF EXTENSION}

We have discussed extension as measured perpendicular to average dike and fault trends, that is, without reference to the regional strain pattern into which it fits. To completely characterize the deformation in Mono Basin, however, the direction as well as the amount of extension must be specified.

\section{Previous Work}

Wright [1976] and Slemmons et al. [1979] suggested that the western Basin Ranges between Walker Lane and the Sierra Nevada is a zone of coeval strike-slip and normal faulting. Within this region, northwest trending faults often display a component of right-lateral motion, whereas northeast trending faults tend to have a component of left-lateral motion.

Evidence gathered along the Sierra Nevada frontal fault zone to the south of the Mono Basin corroborates the regional patterns outlined by Wright [1976] and Slemmons et al. [1979]. Bateman [1965] noted that numerous normal faults of the Volcanic Tableland, southeast of Long Valley Caldera, are arranged in left-stepping echelons associated with broad warps. He showed that northwest trending, distributed right-lateral shear could account for these structural features. In July 1986, earthquakes of the Chalfant Valley Sequence occurred underneath the Volcanic Tableland. Lienkaemper et al. [1987] noted right-lateral slip on faults of the White Mountains frontal fault zone, and leftstepping en echelon fractures in the Volcanic Tableland. Trilateration measurements by Gross and Savage [1987] were compatible with $1.3 \mathrm{~m}$ of right-lateral slip and $0.7 \mathrm{~m}$ of dip slip on a fault dipping $50^{\circ}$ to $55^{\circ}$ southwestward underneath the Tableland. South of the Tableland, the Owens Valley Fault accommodates right-lateral shear as well as extension along the Sierra Nevadan range front, as shown by obliqueslip ground breakage associated with the 1872 Owens Valley Earthquake and previous earthquakes [Beanland and Clark, 1987; Lubetkin and Clark, 1988].

The tension axes of composite focal mechanisms for earthquakes in the region around the Mono Basin are directed west-northwest on average. Focal mechanisms that may be representative of the Mono Basin are those from the Chalfant Valley earthquake sequence, which has a tension axis striking nearly east-west (U.R. Vetter, unpublished manuscript, 1987), or those from the eastern Mono Lake region, for which the tension axis strikes between $\mathrm{N} 50^{\circ} \mathrm{W}$ and $\mathrm{N} 70^{\circ} \mathrm{W}$ [Vetter and Ryall, 1983]. However, the maximum extension axis for earthquake focal mechanisms in the Mam- moth region strikes about $\mathrm{N} 60^{\circ} \mathrm{E}$ [Vetter and Ryall, 1983], probably because of stresses localized around the magma chamber underlying Long Valley Caldera, which may not propagate as far as the Mono Basin.

Trilateration measurements support the inference that maximum extension is west-northwest in the Mono Basin. Data from the Excelsior trilateration network, east of Mono Lake, suggest a $\mathrm{N} 81^{\circ} \pm 7^{\circ} \mathrm{W}$ maximum extension axis, and data from the Owens network, southeast of Mono Basin, suggest a $\mathrm{N} 69^{\circ} \pm 11^{\circ} \mathrm{W}$ axis [Savage, 1983].

\section{Geological Evidence From This Study}

Several pieces of evidence from this study give some indication of the extension direction in the Mono Basin. A horizontal component of slip can be measured from two moraines offset by the range front fault, and trends of other volcanic and tectonic features suggest a sense of motion or extension direction. Offset moraine crests can be used to measure horizontal as well as vertical components of offset, if the positions of the crests are adequately resolved in map view. Because most moraine crests are tens of meters wide, lateral offsets are frequently too small to be resolved, even though vertical offsets are easily measured. At Lundy Canyon, the right-lateral Tioga moraine crest does not appear to be offset laterally. Since the fault trends approximately $\mathrm{N} 3^{\circ} \mathrm{E}$, the maximum extension direction inferred at this locale is $N 87^{\circ} \mathrm{W}$. At Reversed Peak, a N23 ${ }^{\circ} \mathrm{E}$ trending Tahoe morainal bench is offset $21 \mathrm{~m}$ vertically and $30 \mathrm{~m}$ horizontally by the Reversed Peak Fault, which trends $\mathrm{N}^{\circ} 3^{\circ} \mathrm{W}$. Depending on the fault dip, then, the slip vector strikes $\mathrm{N} 27^{\circ} \mathrm{W}$ to $\mathrm{N} 60^{\circ} \mathrm{W}$. The attitudes of these slip vectors suggest that there is a component of right-lateral slip on north-northwest trending range front faults of the Mono Basin and that structures trending north-south to northnortheast accommodate pure extension. Another indicator of right-lateral slip on the range front is the fault at point $D$ in Figure 1, which seems to offset a Tahoe moraine about $50 \mathrm{~m}$ in a right-lateral sense, suggesting that it may have a large right-lateral, strike-slip component. Fissures atop Black Point volcano have been thought to be caused by sediment compaction and adjustment [Custer, 1973], but their trends are consistent with regional tectonics, and the fissures were perhaps formed by a late-stage pulse of a dike. The $\mathrm{N} 27^{\circ} \mathrm{E}$-trending fracture zone extended $\mathrm{N} 24^{\circ} \mathrm{W}$ to $\mathrm{N} 35^{\circ} \mathrm{W}$, based on separations of two corners in the fissure walls.

\section{DisCUSSION}

The following discussion is organized according to the reliability of the data upon which it is based. The first section, therefore, treats extension rates in time slices and makes no reference to more speculative extension directions. The second section deals with the implications of the inferred regional extension direction when coupled with the extension rates. The final section speculates on the possible implications of this work for the formation of large calderas.

\section{Extension Rate}

Figure 10 suggests that before about 70,000 years ago late Quaternary extension in the Mono Basin was taking place rather uniformly on normal faults at or very near the range front. However, since about 70,000 years ago, faulting 
has progressively ceased or slowed on range front segments from Bloody Canyon to the Hartley Springs Fault. Between 70,000 and 40,000 years ago, the range front became inactive at Bloody Canyon. Between 40,000 and 14,000 years ago, the range front became inactive at Parker Canyon, and faults at June Lake were less active than during the preceding period. For the past 14,000 years, extension at June Lake and at Lee Vining Canyon has proceeded at only a fraction of typical range front rates, although measurements for this period are minima. The first indications of volcanism at the Mono Craters occurred within a few tens of thousands of years of the first signs of range front inactivity at Bloody Canyon. From 40,000 to 14,000 years ago, extension due to dike intrusion proceeded at rates comparable to fault slip rates, suggesting that dikes were forming in response to regional crustal stretching. From 14,000 years ago to the present, however, dike intrusion rates seem to be locally greater than faulting rates, suggesting that dikes are intruding in response to high magmatic pressures or magma chamber inflation in addition to crustal stretching. In either case, the result of accommodating extension with dikes rather than faults is a slip gap in the range front fault system.

\section{Relationship of Mono Basin to Regional Tectonic Patterns}

The available geological and geophysical evidence indicates that the maximum extension axis trends about westnorthwest and, therefore, that the north-northwest striking faults of the Sierra Nevadan range front in the Mono Basin are oblique-slip faults with a right-lateral component. The only segments of the range front that may trend orthogonally to the maximum extension direction are those north of and including Bloody Canyon, and north of and including Lundy Canyon. The south central Mono Craters may also trend perpendicular to the maximum extension axis. The hypothetical sense of motion on faults based on this inference is illustrated in Figure 11, in which the Hartley Springs Fault, the Reversed Peak Fault, and the range front fault between Parker and Bloody Canyons constitute one group of left-stepping, oblique-slip echelons, and the Mono Lake Fault and the fault near the northern Mono Craters comprise another left-stepping echelon. The range front at Bloody Canyon and the south and central Mono Craters are features that accommodate extension alone, and are therefore dilational jogs [Sibson, 1987] or opposite edges of a structure similar to a pull-apart basin [Burchfiel and Stewart, 1966]. Activity seems to have traded off between these edges of the pull-apart zone about 40,000 to 70,000 years ago - when the Mono Craters became active and the range front near Bloody Canyon became inactive. This shift in extensional activity resulted in the slip gap discussed in the preceding section. Although the southern Mono Basin is similar to a pull-apart basin in some respects, it differs from one as described by Burchfiel and Stewart [1966] in three significant ways: (1) it occurs between en echelon oblique-slip rather than strike-slip faults, (2) it is asymmetric, since it has been down-dropped on only one edge, and (3) the extensional borders, near Bloody Canyon and at the Mono Craters, have not been active simultaneously.

The volcanic islands of Mono Lake and Black Point are outside the hypothesized pull-apart zone. Gilbert et al. [1968] have explained the locations of volcanoes and structures in this region in a manner that is compatible with the inferred direction of regional extension. Gilbert et al. [1968] suggested that the volcanoes of Mono Lake are related to the "structural knee" of the western Basin Ranges, a region in which bedrock structures rotate from north-northwest trends to northeast trends as they are followed from south to north. The north-northwest trending faults accommodated rightlateral strain, and the northeast trending faults accommodated left-lateral strain. The Cowtrack Mountain range front is an example (Figure 1). The trends of lineaments related to active volcanism and faulting in Mono Lake are parallel to bedrock faults in the structural knee. Gilbert et al. [1968] concluded that Black Point and the volcanoes of Mono Lake are localized at the apex of the knee, where there should be almost pure extension, as exhibited by the Black Point fissures (Figure 11).

Based on the evidence of extension rate and direction data, the process of dike intrusion underneath the Mono Craters may be envisioned as follows. Smith and Bruhn [1984] have shown that most of the stress relief by earthquakes in the Basin Ranges province nucleates at about $10 \mathrm{~km}$ depth. Achauer et al. [1986] have suggested that the roof of the Mono Craters magma chamber is also at a depth of $10 \mathrm{~km}$. Moreover, their work indicates that the chamber is situated under the central segment of the Mono Craters. If the crust at a depth of $10 \mathrm{~km}$ fails, then a magmafilled fracture is likely to propagate where magma pressure is greater than the effective normal stress across the initial break, as may often be the case underneath the central Mono Craters, directly above the magma chamber. A normal fault is likely to propagate from the initial break where magma pressure is low or fractures are less suitably oriented to dilate [Delaney et al., 1986], such as along the Mono Lake or the Hartley Springs Fault, outside the pull-apart zone. As a consequence of the preferential propagation of dikes near the magma chamber, offset events (earthquakes) along the frontal fault are forestalled, and after many dikes have been intruded, a measurable slip gap develops in the range front fault system. Along segments of the range front progressively more remote from the pull-apart zone and the magma chamber, dikes propagate less frequently than normal faults, until the situation is reached where all extension is taken up by faulting, and no volcanic activity occurs.

\section{Implications for Caldera Formation}

Bailey [1982] noted that the Mono Craters are in some ways analogous to Glass Mountain on the northeast rim of Long Valley Caldera, leading him to hypothesize that the craters represent an early phase of caldera formation, since the construction of Glass Mountain directly preceded the formation of Long Valley Caldera. If this is so, then the current tectonic state of Mono Basin is a "snapshot" of the early evolution of Long Valley and perhaps other ash flow calderas, which suggests that they may form in pull-aparts at dilational, en echelon fault jogs; for example, preeruptive [Bacon, 1985] and early [Hildreth and Mahood, 1986] eruptive products as well as the greatest subsidence [Carle, 1988] of Long Valley Caldera are localized at what may have been a pull apart between the Hilton Creek Fault and an east dipping range front fault north of Glass Mountain; Toba Caldera, Indonesia, may be localized at a pull-apart in the Sumatran Fault System [Page et al., 1979]. In such situa- 


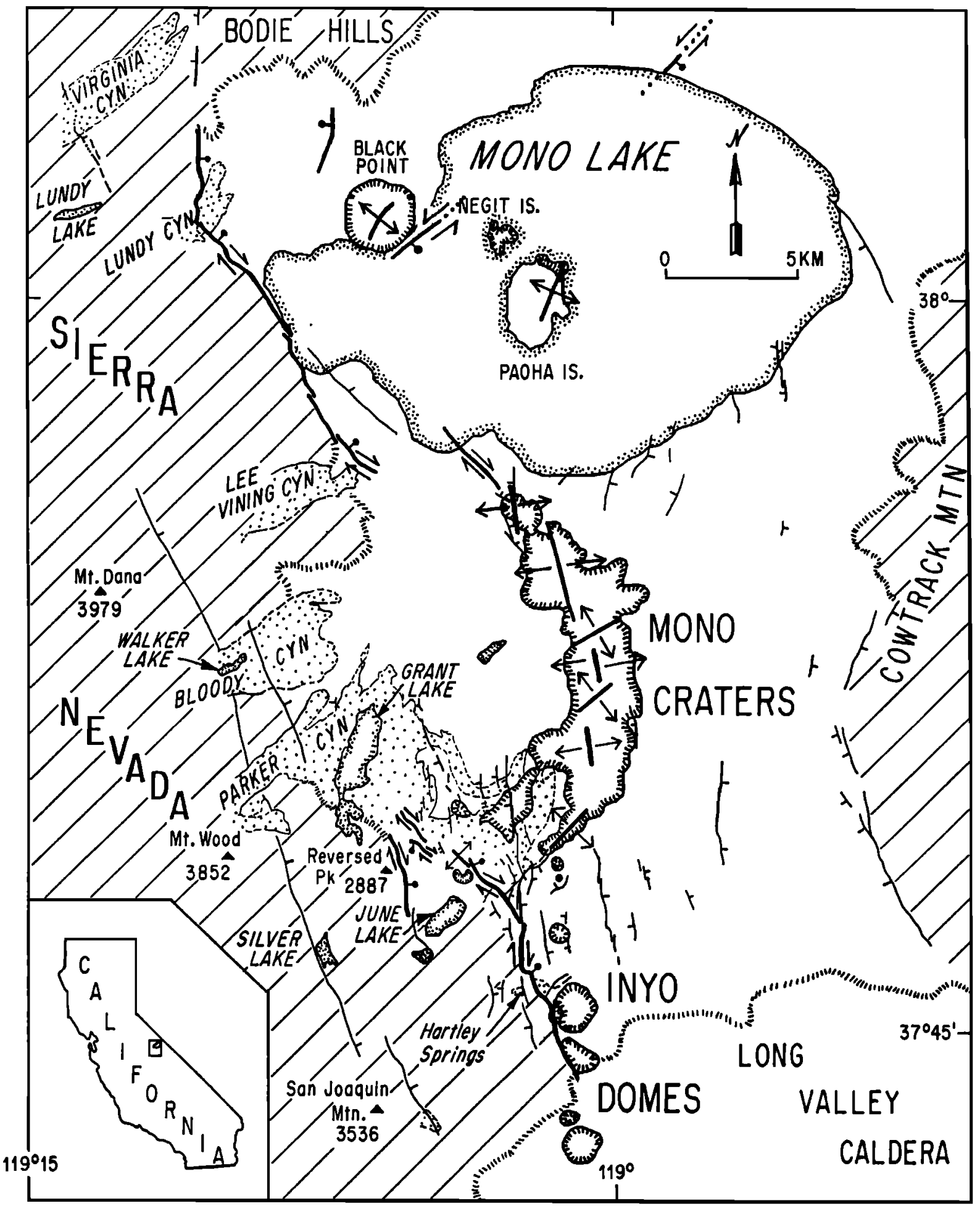

Fig. 11. Schematic diagram of hypothetical sense of motion on groups of faults and fractures in the Mono Basin during the lifetime of the Mono Craters. Data are compatible with extension on north-south to north-northeast trending structures and right-lateral oblique-slip motion on northwest to north-northwest trending structures. 
tions, early products from the magma chamber are erupted along one edge of the pull-apart basin in response to crustal stretching. As the magma chamber enlarges, eruptions may also occur as the result of high magma pressures. Finally, when the chamber becomes sufficiently large, caldera collapse is guided by the boundary faults of the pull-apart basin.

\section{CONCLUSIONS}

The lack of late Quaternary faulting along the Sierra Nevadan range front in the Mono Basin may result from relief of elastic strain by dikes feeding the Mono and Inyo Craters, suggesting that dike intrusion is a part of the earthquake cycle in volcanic regions (Figure 12). Although rates of extension due to dike intrusion were initially similar to faulting rates, overpressurization or inflation of the magma chamber within the past 14,000 years (and especially within the past 5000 years) may be modifying the response of the dike intrusion system so that dikes are injected at an extension rate greater than the tectonic rate.

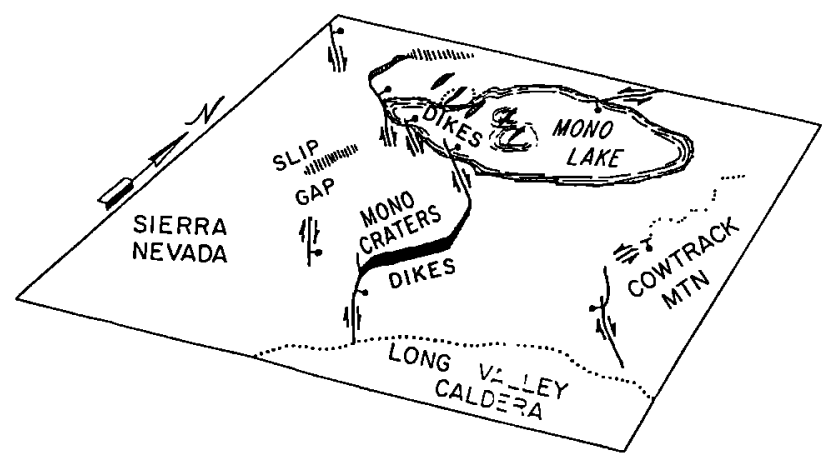

Fig. 12. Perspective diagram illustrating current tectonic relationships in the Mono Basin. Dikes intruding underneath the craters have caused a slip gap in the range front of the Sierra Nevada, because the dikes now accommodate extension that was once taken up by range front normal faults. West-northwestdirected extension results in oblique-slip on north-northwest trending range front faults, and in almost pure extension underneath the south and central Mono Craters, resulting in a structure similar to a pull-apart basin.

Late Quaternary faults define two oblique-slip fault zones along the eastern Sierra Nevadan range front in the Mono Basin. The area within the overlap of the two oblique-slip zones is a pull-apart basin. The Mono Craters have erupted along an extensional bounding structure of the pull-apart basin.

If the Mono Craters represent an early phase of caldera formation, then some large ash flow calderas may have been preferentially localized at pull-apart basins in broad shear zones, in analogy with the setting of the Mono Craters.

Acknowledgments. We thank Leslie Sonder for reading through an earlier version of our manuscript. The work has also benefited from discussions with Malcolm Clark, Charlie Bacon, Roy Bailey, Dan Miller, Craig de Polo and Sylvio Pezzopane. Scott Stine pointed out to us some of the faults near Mono Lake. We thank Ileana Meza, Gregory Ehe, Andy Thomas and Colin Howell for assistance in the field. The Los Angeles Department of Water and Power graciously allowed us to inspect exploratory logs for the Mono Craters Tunnel. Steve Barsi of Lee Vining allowed us to recharge geodimeter batteries. The work was supported by U.S. Geological Survey Earthquake Hazards Reduction Program grants 14-08-0001-22011, -G1098 and -G1370; by Geological Society of America Penrose grant 3547-86, and by the Allan V.C. Davis Foundation. The total station was provided by funds from the W.M. Keck Foundation and by U.S. Geological Survey Earthquake Hazards Reduction Program grant 14-08-0001-G1177.

\section{REFERENCES}

Achauer, U., L. Greene, J.R. Evans, and H.M. Iyer, Nature of the magma chamber underlying the Mono Craters area, eastern California, as determined from teleseismic travel time residuals, J. Geophys. Res., 91, 13873-13891, 1986.

Bacon, C.R., Time-predictable bimodal volcanism in the Coso Range, California, Geology, 10, 65-69, 1982.

Bacon, C.R., Implications of silicic vent patterns for the presence of large crustal magma chambers, J. Geophys. Res., 90, 11243$11252,1985$.

Bacon, C.R., W.A. Duffield, and K. Nakamura, Distribution of Quaternary rhyolite domes of the Coso Range, California: Implications for extent of the geothermal anomaly, J. Geophys. Res., 85, 2425-2433, 1980.

Bajley, R.A., Other potential eruption centers in California: The Long Valley, Mono Lake, Coso, and Clear Lake, volcanic fields, in Status of Volcanic Prediction and Emergency Response Capabilities in Volcanic Hazard Zones of California, edited by R.C. Martin and J.F. Davis, Spec. Publ. Calif. Div. Mines Geol., $63,17-28,1982$.

Bailey, R.A., G.B. Dalrymple, and M.A. Lanphere, Volcanism, structure, and geochronology of Long Valley Caldera-Mono County, California, J. Geophys. Res., 81, 725-744, 1976.

Batchelder, G.L., Postglacial ecology at Black Lake, Mono County, California, Ph.D. thesis, 180 pp., Ariz. State Univ., Tempe, 1970.

Bateman, P.C., Geology and tungsten mineralization of the Bishop District, California, U.S. Geol. Surv. Prof. Pap., 470, 208 pp., 1965.

Beanland, S., and M. Clark, The Owens Valley fault zone, and surface rupture associated with the 1872 earthquake (abstract), Seismol. Res. Lett., 58, 32, 1987.

Berkey, C.P., Revised geologic section of Mono Basin based on later exploration, Memo. XII, 31 pp., Los Angeles Dep. Water and Power, 1935.

Burchfiel, B.C., and J.H. Stewart, "Pull-apart" origin of the central segment of Death Valley, California, Geol. Soc. Am. Bull., $\gamma 7,439-442,1966$.

Bursik, M.I., Late Quaternary volcano-tectonic evolution of the Mono Basin, eastern California, Ph.D. thesis, 270 pp., Calif. Inst. of Technol., Pasadena, 1988.

Carle, S.F., Three-dimensional gravity modeling of the geologic structure of Long Valley Caldera, J. Geophys. Res., 98, 1323713250, 1988.

Chesterman, C.W., and C.H. Gray, Jr., Geology of the Bodie Quadrangle, Mono County, California, Map Sheet Calif. Div. Mines Geol., 21, 1975.

Clark, M.M., Range front faulting: Cause of the difference in height between Mono Basin and Tahoe moraines at Walker Creek, in Field Guide to Relative Dating Methods Applied to Glacial Deposits in the Thind and Fourth Recesses and Along the Eastem Sierra Nevada, California, With Supplementary Notes on Other Sierra Nevada Localities, edited by R.M. Burke and P.W. Birkeland, pp. 54-57, Friends of the Pleistocene Pacific Cell, Menlo Park, 1979.

Crook, R., and A.R. Gillespie, Weathering rates in granitic boulders measured by P-wave speeds, in Rates of Chemical Weathering of Rocks and Minerals, edited by S.M. Colman and D.P. Dethier, pp. 395-417, Academic, San Diego, Calif., 1986.

Custer, S.G., Stratigraphy and sedimentation of Black Point Volcano, Mono Basin, California, M.S. thesis, 114 pp., Univ. of Calif., Berkeley, 1973.

Delaney, P., and D. Pollard, Deformation of host rocks and flow of magma during growth of minette dikes and breccia-bearing intrusions near Ship Rock, New Mexico, U.S. Geol. Surv. Prof. Pap., 1202,61 pp., 1979. 
Delaney, P.T., D.D. Pollard, J.I. Ziony, and E.H. McKee, Field relations between dikes and joints: Emplacement processes and paleostress analysis, J. Geophys. Res., 91, 4920-4938, 1986.

Denham, C.R., and A. Cox, Evidence that the Laschamp polarity event did not occur 13,300-30,400 years ago, Earth Planet. Sci. Lett., 19, 181-190, 1971.

Fink, J.H., Geometry of silicic dikes beneath the Inyo Domes, California, J. Geophys. Res., 90, 11127-11133, 1985.

Fink, J.H., and D.D. Pollard, Structural evidence for dikes beneath silicic domes, Medicine Lake Highland Volcano, California, Geology, 11, 458-461, 1983.

Gilbert, C.M., M.N. Christensen, Y. Al-Rawi, and K.R. Lajoie, Structural and volcanic history of Mono Basin, California Nevada, in Studies in Volcanology, edited by R.R. Coates, R.L. Hay, and C.A. Anderson, Mem. Geol. Soc. Am., 116, 275-329, 1968.

Gillespie, A.R., Quaternary glaciation and tectonism in the southeastern Sierra Nevada, Inyo County, California, Ph.D. thesis, 689 pp., Calif. Inst. of Technol., Pasadena, 1982.

Gross, W.K., and J.C. Savage, Deformation associated with the 1986 Chalfant Valley Earthquake, eastern California, Bull. Seismol. Soc. Am., $\gamma 7$, 306-310, 1987.

Heiken, G., K. Wohletz, and J. Eichelberger, Fracture fillings and intrusive pyroclasts, Inyo Domes, California, J. Geophys. Res., 98, 4335-4350, 1988.

Hildreth, W., and G.A. Mahood, Ring fracture eruption of the Bishop Tuff, Geol. Soc. Am. Bull., 97, 396-403, 1986.

Hill, D.P., E. Kissling, J.H. Luetgert, and U. Kradolfer, Constraints on the upper crustal structure of the Long Valley-Mono Craters volcanic complex, eastern California, from seismic re fraction measurements, J. Geophys. Res., 90, 11135-11150, 1985.

Huber, N.K., Amount and timing of late Cenozoic uplift and tilt of the central Sierra Nevada, California - Evidence from the upper San Joaquin River Basin, U.S. Geol. Surv. Prof. Pap., 1197, 28 pp., 1981.

Kelleher, P., The geology, petrology, and geochemistry of the Mono Craters-Mono Lake Islands volcanic complex, eastern California, M.S. thesis, 111 pp., Univ. of Calif., Santa Cruz, 1986.

Kistler, R.W., Geologic map of the Mono Craters Quadrangle, Mono and Tuolomne Counties, California, U.S. Geol. Surv. Quad rangle Map, GQ-462, 1966.

Lachenbruch, A.H., and J.H. Sass, Models of an extending lithosphere and heat flow in the Basin and Range province, in Cenozoic Tectonics and Regional Geophysics of the Western Cordillera, edited by R.B. Smith and G.P. Eaton, Mem. Geol. Soc. Am., 152, 209-250, 197.

Lajoie, K.R, Late Quaternary stratigraphy and geologic history of Mono Basin, eastern California, Ph.D. thesis, 271 pp., Univ. of Calif., Berkeley, 1968.

Lajoie, K.R., and S.W. Robinson, Late Quaternary glacio lacustrine chronology Mono Basin, California, Geol. Soc. Am Abstr. Programs, 14, 179, 1982.

Lienkaemper, J.J., S.K. Pezzopane, M.M. Clark, and M.J. Rymer, Fault fractures formed in association with the 1986 Chalfant Valley, California, earthquake sequence: preliminary report, Bull. Seismol. Soc. Am., 77, 297-305, 1987.

Loney, R.A., Flow structure and composition of the Southern Coulee, Mono Craters, California - A pumiceous rhyolitic flow, in Studies in Volcanology, edited by R.R. Coates, R.L. Hay, and C.A. Anderson, Mem. Geol. Soc. Am., 116, 415-440, 1968.

Lubetkin, L.K.C., Late Quaternary activity along the Lone Pine Fault, Owens Valey Fault Zone, California, Ph.D. thesis, 85 pp., Stanford Univ., 1980.

Lubetkin, L.K.C., and M.M. Clark, Late Quaternary activity along the Lone Pine fault, eastern California, Geol. Soc. Am. Bull., 100, 755-766, 1988.

Mastin, L.G., and D.D. Pollard, Surface deformation and shallow dike intrusion processes at Inyo Craters, Long Valley, California, J. Geophys. Res., 98, 13221-13235, 1988.

Miller, C.D., Holocene eruptions at the Inyo volcanic chain, California: Implications for possible eruptions in Long Valley Caldera, Geology, 19, 14, 1985.

Muller, O.H., and D.D. Pollard, The stress state near Spanish
Peaks, Colorado determined from dike pattern, Pure Appl. Geophys., 115, 69-86, 1977.

Myers, W.B., and W. Hamilton, Deformation accompanying the Hebgen Lake Earthquake of August 17, 1959, in The Hebgen Lake, Montana, Earthquake of August 17, 1959, U.S. Geol. Surv. Prof. Pap., 485, 55-98, 1964.

Nakamura, K., Volcanoes as possible indicators of tectonic stress orientation - Principle and proposal, J. Volcanol. Geotherm. Res., 2, 1-16, 1977.

Nash, D.B., Morphologic dating of degraded normal fault scarps, J. Geol., 88, 353-360, 1980.

Ode, H., Mechanical analysis of the dike pattern of the Spanish Peaks area, Colorado, Geol. Soc. Am. Bull., 68, 567-576, 1957.

Page, B.G.N., J.D. Bennett, N.R. Cameron, D.M. Bridge, D.H Jeffery, W. Keats, and J. Thaib, A review of the main structural and magmatic features of northern Sumatra, J. Geol. Soc. London, 196, 569-579, 1979.

Page, B.M., Basin-Range faulting of 1915 in Pleasant Valley, Nevada, J. Geol., 48, 690-707, 1934.

Pakiser, L.C., Seismic exploration of Mono Basin, California, $J$. Geophys. Res., 81, 3607-3618, 1976.

Pakiser, L.C., F. Press, and M.F. Kane, Geophysical investigation of Mono Basin, California, Geol. Soc. Am. Bull., 71, 415-448, 1960.

Pelagos Corporation, A bathymetric map and geologic survey of Mono Lake, California, 38 pp., with appendices and maps, Los Angeles, 1987.

Putnam, W.C., Quaternary geology of the June Lake district, California, Geol. Soc. Am. Bull., 60, 1281-1302, 1949.

Roquemore, G., Structure, tectonics, and stress field of the Coso Range, Inyo County, California, J. Geophys. Res., 85, 2434-2440, 1980

Russell, I.C., Quaternary history of Mono Valley, U.S. Geol. Surv. Eighth Annual Report, 267-394, 1889.

Sampson, D.E., Textural heterogeneities and vent area structures in the $\mathbf{6 0 0}$ year old lavas of the Inyo volcanic chain, eastern California, in The Emplacement of Silicic Domes and Lava Flows, edited by J.H. Fink, Spec. Pap. Geol. Soc. Am., 212, 89-101, 1987.

Sanders, C.O., Location and configuration of magma bodies beneath Long Valley, California, determined from anomalous earthquake signals, J. Geophys. Res., 89, 8287-8302, 1984.

Savage, J.C., Strain accumulation in the western United States, Annu. Rev. Earth Planet. Sci., 11, 11-43, 1983.

Sibson, R.H., Earthquake rupturing as a mineralizing agent in hydrothermal systems, Geology, 15, 701-704, 1987.

Sieh, K.E., and M.I. Bursik, Most recent eruption of the Mono Craters, eastern central California, J. Geophys. Res., 91, 12539 12571, 1986.

Slemmons, D.B., Geological effects of the Dixie Valley-Fairview Peak, Nevada, Earthquake of December 16, 1954, Bull. Seiomol. Soc. Am., 47, 353-375, 1957.

Slemmons, D.B., D. Van Wormer, E.J. Bell, and M.L. Silberman, Recent crustal movements in the Sierra Nevada-Walker Lane region of California-Nevada, I, Rate and style of deformation, Tectonophysics, 52, 561-570, 1979.

Smith, R.B., and R.L. Bruhn, Intraplate extensional tectonics of the eastern Basin-Range: Inferences on structural style from seismic reflection data, regional tectonics and thermalmechanical models of brittle/ductile deformation, J. Geophys. Res., 89, 5733-5762, 1984.

Speight, J.M., R.R. Skelhorn, T. Sloan, and R.J. Knapp, The dyke swarms of Scotland, in Igneous Rocks of the British Isles, edited by D.S. Sutherland, pp. 449-459, Wiley-Interscience, New York, 1982.

Stine, S., Mono Lake: the past 4000 years, Ph.D. thesis, 615 pp., Univ. of Calif., Berkeley, 1987.

Swan, F.H., III, D.P. Schwartz, and L.S. Cluff, Recurrence of moderate to large magnitude earthquakes produced by surface faulting on the Wasatch Fault Zone, Utah, Bull. Seismol. Soc. Am., 70, 1431-1462, 1980.

Vetter, U.R., and A.S. Ryall, Systematic change of focal mechar nism with depth in the western Great Basin, J. Geophys. Res., 88, 8237-8250, 1983.

Walker, G.P.L., Koolau dike complex, Oahu: Intensity and origin 
of a sheeted-dike complex high in a Hawaiian volcanic edifice, Geology, 14, 310-313, 1986.

Wallace, R.E., Profiles and ages of young fault scarps, northcentral Nevada, Geol. Soc. Am. Bull., 88, 1267-1281, 1977.

Witkind, I.J., Reactivated faults north of Hebgen Lake, in The Hebgen Lake, Montana, Earthquake of August 17, 1959, U.S. Geol. Surv. Prof. Pap., 495, 37-50, 1964.

Wood, S.H., Chronology of late Pleistocene and Holocene volcanics, Long Valley and Mono Basin geothermal areas, eastern California, final technical report, 78 pp., U.S. Geol. Surv. Geotherm. Res., Extramural Programs, Loo Angeles, 1977. (Reprinted as U.S. Geol. Surv. Open File Rep., 8747, 76 pp., 1983).

Wood, S.H., Obsidian hydration-rind dating of the Mono Craters, in Geologic Guide to Aspen Valley, Mono Lake, Mono Craters, and Inyo Chaters, pp. 82-87, Genny Smith Books, Palo Alto, Calif., 1984.
Wright, L., Late Cenozoic fault patterns and stress fields in the Great Basin and westward displacement of the Sierra Nevada block, Geology, 4, 489-494, 1976.

M. Bursik, Department of Earth Sciences, University of Cambridge, Cambridge CB2 3EQ, England.

K. Sieh, Division of Geological and Planetary Sciences, California Institute of Technology, Pasadena, CA 91125.

(Received August 22, 1988;

(revised March 30, 1989;

accepted April 27, 1989.) 